\title{
EVALUASI PENERAPAN MANAJEMEN RISIKO PADA STRATEGI PENGELOLAAN UTANG PEMERINTAH INDONESIA PERIODE 2005 - 2014
}

\author{
Des Dhoni Wiastanto \\ Direktorat Sistem Perbendaharaan \\ Alamat Korespondensi: des.dhoni@gmail.com
}

\section{INFORMASI ARTIKEL}

Diterima Pertama

15 Juni 2016

Dinyatakan Diterima

30 Juli 2018

KATA KUNCI:

Pengelolaan Utang Pemerintah, Manajemen Risiko, Nilai Tukar, Tingkat Bunga, Likuiditas, Kesinambungan Fiskal

KLASIFIKASI JEL:

G32, H63

\begin{abstract}
Deficit financing using debt has various risks to be faced, such as the risk of changes in exchange rates, interest rates, refinancing, and fiscal sustainability. To anticipate those risks, the Government of Indonesia formulates a debt management strategy in which there are risk indicator targets to be achieved. This study aimed to find out and understand the risks of debt management, which policies that have been conducted by the Government of Indonesia in order to manage those risks, and how the various achievements over the target risk indicators that have been determined. The method used is a qualitative descriptive describing each type of risk and explain the various factors that influence it. The data used consist of primary data sourced from indepth interviews with some experts and secondary data obtained from the literature as well as other publications. The results showed that some of the risk indicators of fiscal sustainability are not achieved. In addition, there are some implementation of policies that have not been optimal, such as the hedging transaction has not been implemented yet, the Asset - Liability Management implementation which is still limited in liquidity aspect, and the differences in perspective between debt management unit and cash management unit in terms of debt issuance strategy in the beginning of the year (front loading).
\end{abstract}

\section{ABSTRAK}

Pembiayaan defisit menggunakan utang memiliki berbagai risiko yang harus dihadapi, seperti risiko perubahan nilai tukar, tingkat bunga, pembiayaan kembali, dan kesinambungan fiskal. Untuk mengantisipasi risiko tersebut, Pemerintah Indonesia menyusun strategi pengelolaan utang yang di dalamnya terdapat target indikator risiko yang ingin dicapai. Penelitian ini bertujuan untuk memahami risiko pengelolaan utang, kebijakan apa saja yang telah dilakukan oleh Pemerintah Indonesia dalam rangka mengelola risiko tersebut, dan bagaimana capaian atas target indikator risiko. Metode penelitian yang digunakan adalah deskriptif kualitatif dengan menguraikan setiap jenis risiko, dan menjelaskan berbagai faktor yang mempengaruhinya. Data yang digunakan terdiri dari data primer yang bersumber dari wawancara mendalam dengan narasumber pelaku dan data sekunder yang bersumber dari literatur serta publikasi lainnya. Hasil penelitian menunjukkan bahwa beberapa indikator risiko kesinambungan fiskal tidak tercapai. Selain itu, ditemukan beberapa pelaksanaan kebijakan yang belum optimal, yaitu belum dilaksanakannya transaksi lindung nilai, pelaksanaan Asset-Liability Management yang masih terbatas pada likuiditas, dan perbedaan perspektif antara unit pengelola utang dan unit pengelola kas dalam hal strategi penerbitan utang di awal tahun (front loading). 


\section{PENDAHULUAN}

\subsection{Latar Belakang}

Perubahan prinsip penganggaran dari semula menganut "anggaran berimbang" menjadi "anggaran suplus/defisit" membawa konsekuensi adanya komponen penting lainnya dalam APBN selain pendapatan dan belanja, yaitu pembiayaan untuk memenuhi selisih lebih/kurang dari pendapatan dan belanja. Sejak disusun dengan prinsip tersebut pertama kali pada tahun 2005, APBN selalu mengalami defisit. Untuk memenuhi defisit tersebut dibutuhkan pembiayaan yang dapat bersumber baik dari utang maupun non utang, walaupun dalam praktiknya pembiayaan menggunakan utang memiliki porsi yang lebih besar dibandingkan pembiayaan yang bersumber dari non utang. Sebagai contoh, pada tahun 2014 pembiayaan non utang sebesar Rp543,4 miliar sedangkan pembiayaan dengan utang mencapai Rp318,2 triliun.

Pembiayaan dengan utang memiliki risiko yang terkait dengan kondisi perekonomian dan pasar keuangan baik domestik maupun global. Beberapa risiko tersebut di antaranya adalah risiko nilai tukar, risiko tingkat bunga, risiko pembiayaan kembali dan risiko kesinambungan fiskal. Untuk mengantisipasi berbagai risiko tersebut, Pemerintah Indonesia, dalam hal ini diwakili oleh Direktorat Jenderal Pengelolaan Pembiayaan dan Risiko (DJPPR), telah menyusun dan melaksanakan strategi pengelolaan utang jangka menengah (tiga sampai lima tahunan) dan jangka pendek (tahunan). Strategi tersebut berisi langkah-langkah kebijakan yang ditempuh dalam rangka pengelolaan utang termasuk target indikator risiko yang diharapkan.

Pada periode 2005 s.d. 2014, perekonomian dan pasar keuangan Indonesia beberapa kali mengalami tekanan akibat krisis keuangan global, yang dipicu oleh krisis Subprime Mortgage di Amerika Serikat, krisis utang di Eropa, dan perlambatan pertumbuhan ekonomi Tiongkok. Kondisi tersebut secara tidak langsung menyebabkan indikator risiko pengelolaan utang Pemerintah terutama yang berdenominasi asing menjadi lebih tinggi.

\subsection{Manfaat Penelitian}

1.2.1. Dari aspek akademis, hasil penelitian diharapkan dapat memberi pemahaman lebih baik tentang berbagai risiko yang dapat timbul dalam pengelolaan utang Pemerintah, dan langkah-langkah yang dapat dilakukan untuk mengantisipasi risiko tersebut;

1.2.2. Dari aspek praktis, hasil penelitian diharapkan menjadi bahan evaluasi
Pemerintah, khususnya unit pengelola utang, dalam rangka manajemen risiko pengelolaan utang.

\subsection{Tujuan Penelitian}

Berdasarkan latar belakang tersebut, tujuan penelitian ini adalah:

1.3.1. Mengidentifikasi dan menganalisis risiko pengelolaan utang Pemerintah beserta faktor yang mempengaruhinya;

1.3.2. Mengetahui kebijakan atau langkah-langkah yang dilakukan untuk mengelola risiko tersebut;

1.3.3. Mengetahui dampak dari pengelolaan risiko dan capaian target indikator risiko yang telah ditentukan.

\section{KERANGKA TEORI}

\subsection{Kebijakan Pembiayaan Defisit}

Komponen utama APBN adalah pendapatan, belanja dan pembiayaan. Defisit APBN merupakan kondisi yang terjadi akibat belanja negara yang lebih besar daripada pendapatan. Defisit APBN pada dasarnya memang direncanakan dengan tujuan untuk mendorong dan menjaga momentum pertumbuhan ekonomi melalui government expenditures seperti belanja modal, infrastruktur atau investasi pemerintah lainnya. Selain itu kebijakan APBN Indonesia yang menganut adanya mandatory spending seperti sektor pendidikan (20 persen APBN, UUD 1945 Pasal 34 ayat 1), sektor kesehatan (5 persen APBN, UU Nomor 36 Tahun 2009 tentang Kesehatan), dan Dana Alokasi Umum (UU Nomor 33 Tahun 2004 tentang Perimbangan Keuangan Pusat dan Daerah) juga menyebabkan ruang gerak fiskal yang terbatas untuk alokasi belanja pemerintah lainnya, sehingga mendorong terciptanya defisit anggaran.

Selain faktor-faktor yang telah disebut di atas, Haryati (2001, dalam Bafadal, 2005, 21) mengungkapkan penyebab terjadinya defisit anggaran adalah karena melesetnya asumsi-asumsi makroekonomi dalam penyusunan APBN sehingga target-target pendapatan dan belanja negara tidak tercapai. ${ }^{1}$ Namun dalam rangka menjaga kesinambungan fiskal dan stabilitas ekonomi, sesuai dengan standar Maastrict Treaty yang kemudian diadopsi dalam UU Keuangan Negara, defisit APBN dibatasi maksimal 3 persen dari Produk Domestik Bruto negara pada tahun yang sama.

1 Azhar Bafadal, Dampak Defisit dan Utang Pemerintah Terhadap Stabilitas Makro Ekonomi. Bogor: Institut Pertanian Bogor. Disertasi, 2005, hlm. 21. 
Defisit APBN dapat memiliki pengaruh terhadap inflasi, jika pembiayaan defisit diarahkan kepada pencetakan uang. Akan tetapi, Agenor dan Montiel (1996, dalam Bafadal, 2005, 64) menyebutkan bahwa pada umumnya di negaranegara berkembang, hubungan antara defisit dan inflasi adalah lemah. ${ }^{2}$ Hubungan yang lemah tersebut disebabkan: (1) defisit anggaran dapat dibiayai dengan menerbitkan bond dibandingkan dengan mencetak uang; (2) perubahan komposisi sumber pembiayaan defisit, misalnya substitusi pinjaman dari luar negeri dengan pinjaman dalam negeri, mengimplikasikan inflasi yang relatif rendah tanpa mengurangi defisit anggaran; (3) korelasi antara defisit anggaran dan inflasi rendah jika permintaan uang tidak stabil, karena ekspektasi yang lambat dalam penyesuaian; (4) keberadaan ekspektasi yang kuat mempengaruhi keterkaitan terhadap persepsi tentang kebijakan pemerintah di masa yang akan datang.

Defisit APBN juga memengaruhi tingkat bunga riil dan struktur pasar finansial, terutama jika defisit tersebut dibiayai dengan pinjaman langsung kepada masyarakat. Hal itu dapat disebabkan oleh dua alasan utama: (1) tingkat kepercayaan masyarakat atas pengelolaan anggaran dan kesinambungan fiskal menurun ketika pemerintah menerbitkan utang untuk membiayai defisit, akibatnya permintaan atas bond juga menurun, sehingga untuk menarik minat masyarakat maka suku bunga akan didorong untuk naik; (2) ketika penawaran bond meningkat sementara permintaan cenderung tetap, harga akan turun dan dibutuhkan kenaikan suku bunga yang dapat menarik masyarakat untuk membeli bond tersebut. Namun Hossain dan Chowdhury (1998, dalam Bafadal, 2005, 65) menyebutkan bahwa pada tahun 1980 dan 1994 di negara-negara berkembang tidak terdapat hubungan yang kuat antara defisit anggaran dan tingkat suku bunga riil. ${ }^{3}$

Dalam perspektif lain, Cavallo $(2005,1)$ mengungkapkan bahwa defisit anggaran juga dapat memengaruhi defisit current account. ${ }^{4}$ Hubungan tersebut dapat diamati melalui Keynesian Model berikut (Keynes, 1936):

\section{$\mathrm{Y}=\mathrm{C}+\mathrm{S}+\mathrm{T}=\mathrm{C}+\mathrm{I}+\mathrm{G}+\mathrm{X}-\mathrm{M}$}

Dimana:

$\mathrm{Y}=$ Pertumbuhan Ekonomi

$\mathrm{C}=$ Konsumsi

2 Ibid, hlm. 64.

3 Ibid, hlm. 65.

4 Michele Cavallo, Understanding the Twin Deficits: New Approaches, New Result. San Fransisco: Federal Reserve Bank of San Fransisco, 2005, hlm.1.

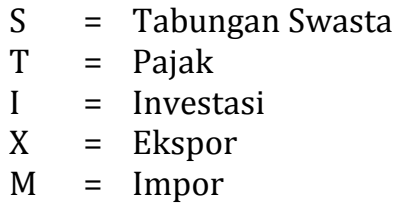

Persamaan tersebut kemudian dapat dituliskan kembali dalam bentuk:

$$
(\mathrm{M}-\mathrm{X})=(\mathrm{I}-\mathrm{S})+(\mathrm{G}-\mathrm{T})
$$

Persamaan di atas dikenal dengan hubungan defisit kembar (twin-deficit relationship), yang menyatakan bahwa defisit neraca perdagangan (MX) sama dengan selisih dari investasi swasta terhadap tabungan masyarakat (I-S) ditambah defisit atau surplus anggaran (G-T). Bluedorn (2011, 600) menyatakan bahwa terdapat hubungan antara defisit anggaran terhadap defisit neraca berjalan, yaitu 1 persen konsolidasi fiskal yang dilakukan Pemerintah dapat menyebabkan penurunan 0,6 persen rasio defisit neraca berjalan terhadap PDB. Namun untuk memperoleh hubungan defisit kembar tersebut, diasumsikan selisih investasi swasta terhadap tabungan masyarakat (I-S) adalah tetap, sehingga peningkatan atau penurunan defisit anggaran dapat diartikan juga sebagai peningkatan atau penurunan pada defisit neraca perdagangan.

Untuk menutup defisit yang timbul dalam APBN, dibutuhkan pembiayaan yang relatif murah, sehingga tidak menimbulkan beban berlebih pada APBN tahun-tahun berikutnya dan tidak menimbulkan dampak negatif dalam perekonomian (Widodo, 2005, 20). Oleh karena itu kebijakan umum terkait pembiayaan defisit diarahkan pada beberapa poin penting, yaitu: (1) Mengendalikan rasio akumulasi utang terhadap PDB; (2) Mengutamakan pembiayaan utang yang bersumber dari dalam negeri; (3) Mengarahkan pemanfaatan utang untuk kegiatan produktif; dan (4) Memanfaatkan pinjaman luar negeri secara selektif utamanya untuk sektor infrastruktur dan energi.

\subsection{Konsep Utang Pemerintah}

Utang suatu negara terdiri dari utang Pemerintah dan utang swasta. Utang pemerintah dapat bersumber dari dalam dan luar negeri. Utang dalam negeri dapat berupa pinjaman langsung kepada masyarakat dalam bentuk penjualan Surat Berharga Negara (SBN) atau pinjaman tidak langsung dengan cara mencetak uang. Sedangkan utang luar negeri dapat berupa pinjaman dari kerjasama bilateral atau multilateral.

Pandangan tradisional terkait utang Pemerintah dalam Mankiw $(2006,428)$ berasumsi bahwa ketika Pemerintah melakukan pemotongan pajak sehingga anggaran menjadi defisit, masyarakat sebagai konsumen akan tergerak 
untuk melakukan belanja konsumsi lebih besar karena disposable income yang tersedia juga lebih besar. Efeknya dalam jangka pendek permintaan atas barang dan jasa mengalami peningkatan, sehingga output dan kesempatan kerja juga akan terdorong naik. Namun kemudian defisit anggaran akan dibiayai dengan utang yang mengurangi tabungan nasional (national saving), dan akan menyebabkan berkurangnya dana yang tersedia di masyarakat untuk diinvestasikan sehingga tingkat bunga akan naik. Kenaikan tingkat bunga akan membebani investor domestik, sementara di sisi lain mendorong aliran modal dari luar negeri untuk masuk ke pasar keuangan dalam negeri. Akibatnya Rupiah akan cenderung terapresiasi dan produk dalam negeri akan menjadi tidak kompetitif. Dengan kata lain, defisit dan utang Pemerintah dalam jangka panjang akan menurunkan ketersediaan modal domestik dan sebaliknya utang luar negeri yang meningkat, sehingga justru akan menekan pertumbuhan ekonomi.

Pandangan lain diungkapkan oleh Ricardo (1820, dalam Mankiw, 2006, 436) yang mengungkapkan bahwa perilaku konsumsi tidak semata-mata dipengaruhi oleh pemotongan pajak dan kebijakan defisit Pemerintah, tetapi juga mempertimbangkan pendapatan di masa depan. Karena untuk membayar utang yang digunakan untuk membiayai defisit saat ini, Pemerintah harus meningkatkan pendapatan pajak di masa depan dan mengakumulasi modal. Dengan kata lain, kebijakan pemotongan pajak saat ini hanya bersifat penjadwalan ulang pendapatan pajak ke masa depan. Dengan asumsi tersebut, maka Ricardo (1820, dalam Mankiw, 2006, 436) menyatakan bahwa tingkat konsumsi rumah tangga tidak terpengaruh, karena rumah tangga akan menabung kelebihan disposable income untuk mengantisipasi kelebihan pajak di masa depan. Peningkatan tabungan swasta tersebut akan membantu menutup penurunan tabungan pemerintah, sehingga tabungan nasional akan cenderung tetap sama.

Utang Pemerintah juga dianggap memiliki pengaruh terhadap permintaan agregat. Pougue dan Sgontz (1978, dalam Bafadal, 2005, 27) menyebutkan bahwa permintaan barang dan jasa pada tingkat belanja Pemerintah tertentu akan lebih besar jika dibiayai dengan utang dibandingkan hanya dibiayai dengan pajak.

\subsection{Pengelolaan Utang Pemerintah}

IMF dan World Bank $(2014,5)$ menyebutkan bahwa pengelolaan utang merupakan suatu proses dalam membuat dan melaksanakan strategi pengelolaan utang Pemerintah agar dapat dikendalikan pada tingkat biaya dan risiko yang dapat ditoleransi, serta untuk memenuhi tujuan lainnya. Adapun tujuan umum pengelolaan utang adalah: (1) menjamin terpenuhinya financing gap dan ketahanan fiskal yang berkesinambungan; (2) meningkatkan prinsip kehati-hatian dalam pengelolaan utang terutama untuk meminimalkan risiko; dan (3) mengembangkan upaya-upaya agar pinjaman yang telah direncanakan dapat dilaksanakan sesuai jadwal dan perkiraan biaya.

Sedangkan terkait dengan struktur organisasi/ lembaga pengelola utang Pemerintah bisa jadi berbeda di setiap negara. Namun Bangura, Kitabire dan Powell (2000, dalam Bafadal, 2005, 42) mengungkapkan bahwa tugas dan fungsi lembaga tersebut akan berkisar pada: (1) memformulasikan kebijakan dan strategi pengelolaan utang; (2) menyediakan analisis dan proyeksi makroekonomi untuk mendukung pembuatan kebijakan; dan (3) melaksanakan kegiatan untuk mengimplementasikan kesepakatan pinjaman dan menjaga data pinjaman. Masih menurut Bangura, Kitabire dan Powell (2000, dalam Bafadal, 2005, 43) terdapat dua elemen kunci dalam pengelolaan utang, yaitu formulasi strategi dalam menangani besaran dan komposisi utang, serta memonitor dan menjaga informasi utang luar negeri.

\subsection{Konsep Risiko}

Secara sederhana risiko dapat diartikan sebagai prospek suatu hasil yang tidak disukai (Keown dan David, 2000, 190). Definisi lain dinyatakan oleh Hanafi (2006) bahwa risiko merupakan besarnya tingkat pengembalian yang diharapkan dibandingkan dengan tingkat pengembalian aktual. Vaughan dan Elliott $(2008,2)$ mendefinisikan risiko sebagai berikut: (1) kans akan terjadinya kerugian; (2) kemungkinan akan terjadinya kerugian; (3) ketidakpastian; (4) penyimpangan kenyataan dari hasil yang diharapkan; dan (5) probabilitas bahwa suatu hasil berbeda dari yang diharapkan.

Risiko yang dihadapi oleh setiap industri berbeda-beda sesuai dengan karakteristik bisnis yang dilakukan. Pada industri keuangan, menurut Horcher $(2005,3)$ risiko dapat timbul karena tiga hal, yaitu: (1) perubahan kondisi pasar; (2) tindakan dan transaksi dengan pihak eksternal seperti vendor, pelanggan, dan pihak ketiga lainnya; dan (3) kegagalan internal organisasi yang disebabkan karena personel, prosedur dan sistem. Horcher $(2005,23)$ juga mengungkapkan berbagai jenis risiko yang dapat terjadi di sektor keuangan, yaitu risiko pasar, risiko kredit, risiko likuiditas dan risiko operasional. Adapun risiko pasar masih dapat terbagi lagi menjadi risiko nilai tukar, risiko tingkat bunga, risiko harga komoditas dan risiko harga ekuitas. 


\subsection{Konsep Manajemen Risiko Pengelolaan Utang Pemerintah}

Manajemen risiko sebagaimana dinyatakan oleh Djojosoedarso (2003) merupakan berbagai cara untuk menanggulangi risiko. Sedangkan Peltier (2001) mengartikan manajemen risiko sebagai proses mengidentifikasi, mengukur dan mengurangi risiko. Definisi yang serupa disampaikan oleh Ikatan Bankir Indonesia (2015) bahwa manajemen risiko merupakan serangkaian metodologi dan prosedur yang digunakan untuk mengidentifikasi, mengukur, memantau, dan mengendalikan risiko.

Manajemen risiko merupakan inti dari manajemen strategi setiap organisasi, dimana secara sistemik organisasi akan mengidentifikasi berbagai risiko yang melekat pada aktivitas dalam rangka mencapai tujuan (Institute of Risk Management, 2002, 2). Agar dapat berjalan dengan efektif, manajemen risiko harus dilaksanakan dan dikembangkan secara terus menerus dalam strategi yang diterapkan oleh entitas. Selain itu manajemen risiko juga harus secara terorganisasi dapat merespon segala bentuk risiko yang telah, sedang dan akan dihadapi baik di masa lalu, saat ini dan utamanya di masa depan.

Terdapat beberapa versi tahapan manajemen risiko, namun secara umum Insititute of Risk Management $(2002,5)$ menyatakan bahwa tahapan tersebut adalah sebagai berikut: (1) Risk Assessment, untuk mengidentifikasi, menganalisis dan mengevaluasi profil risiko dibandingkan dengan kriteria risiko yang dimiliki entitas; (2) Risk Reporting \& Communication, yaitu menyampaikan informasi hasil evaluasi profil risiko kepada stakeholders untuk kemudian menentukan perlakuan terhadap risiko tersebut; (3) Risk Treatment, dapat dilakukan dengan cara: menghindari risiko, membagi risiko, mengurangi risiko, memindahkan risiko, atau menerima risiko; dan (4) Monitoring, untuk mengetahui apakah masih terdapat risiko yang belum teratasi.

Manajemen risiko sebagai fokus utama dalam pengelolaan utang Pemerintah dinyatakan oleh Storkey $(2010,8)$. Menurutnya, pengelola utang harus mengantisipasi risiko yang dapat memberikan dampak negatif terhadap keuangan negara. Terdapat tiga pertimbangan yang mendasari pemikiran tentang pentingnya manajemen risiko dalam pengelolaan utang Pemerintah, yaitu: (1) masyarakat cenderung menghindar dan menolak risiko dalam pengambilan keputusan, sehingga masyarakat berharap Pemerintah juga dapat memiliki sikap yang sama dalam mengelola keuangannya; (2) kerugian dalam portofolio utang Pemerintah akan menimbulkan beban biaya yang besar, oleh karena itu manajemen risiko dibutuhkan untuk menekan risiko yang timbul akibat ketidakpastian sekaligus menyediakan tingkat kepastian yang lebih baik dalam perencanaan pengelolaan utang; (3) Pemerintah tidak memiliki keunggulan kompetitif dibandingkan para pelaku pasar lainnya dalam memperoleh keuntungan yang lebih besar dari pengelolaan utang. Kelebihan yang dimiliki Pemerintah adalah karena dapat memperoleh sumber informasi internal terkait kondisi fiskal dan kebijakan Pemerintah lainnya, namun kebanyakan Pemerintah menganggap bahwa terlalu mengeksploitasi informasi internal itu tidaklah etis.

\section{METODOLOGI PENELITIAN}

\subsection{Jenis Penelitian}

Penelitian ini menggunakan pendekatan penelitian kualitatif. Menurut Corbin dan Strauss (1998, dalam Sujarweni, 2014, 6) penelitian kualitatif merupakan jenis penelitian yang menghasilkan penemuan-penemuan yang tidak dapat dicapai atau diperoleh menggunakan prosedur-prosedur statistik atau cara-cara lain dari kuantifikasi (pengukuran). Hal itu sejalan dengan pernyataan Afrizal $(2014,13)$ bahwa penelitian kualitatif akan menganalisis data berupa kata-kata dan perbuatan manusia tanpa berusaha untuk mengkuantifikasikannya.

\subsection{Jenis, Sumber dan Cara Perolehan Data}

Jenis data yang digunakan dalam penelitian ini terbagi menjadi dua, primer dan sekunder. Data primer diperoleh melalui pernyataan langsung dari narasumber ahli di Kementerian Keuangan sebagai informan pelaku yang diperoleh melalui wawancara mendalam. Sedangkan data sekunder diperoleh melalui studi kepustakaan atas naskah akademis seperti jurnal ilmiah, working paper/ policy paper, dan buletin/ majalah terbitan lembaga keuangan multilateral, serta berbagai laporan terkait profil dan portofolio utang yang dikelola oleh Pemerintah dalam periode yang dimaksud dalam penelitian ini.

\subsection{Definisi Operasional}

Risiko nilai tukar merupakan risiko yang timbul akibat fluktuasi nilai tukar Rupiah terhadap mata uang Internasional dan/atau negara pemberi pinjaman. Ketika Rupiah mengalami depresiasi terhadap mata uang pembanding, beban utang berdenominasi asing akan bertambah besar, begitu pula sebaliknya. Indikator risiko nilai tukar diukur berdasarkan rasio porsi utang berdenominasi terhadap total utang. Semakin tinggi nilai rasio tersebut, semakin tinggi pula eksposur atas risiko nilai tukar 
Risiko tingkat bunga adalah merupakan risiko yang timbul akibat fluktuasi tingkat bunga pasar yang dipengaruhi oleh berbagai faktor, salah satunya tingkat bunga acuan Bank Indonesia (BI rate). Fluktuasi tingkat bunga akan berpengaruh langsung terhadap besaran beban bunga yang harus dibayar Pemerintah atas utang yang menggunakan bunga mengambang (floating rate). Indikator risiko tingkat bunga diukur dari rasio utang dengan bunga tetap terhadap total utang. Semakin tinggi nilai rasio tersebut, semakin rendah eksposur atas risiko tingkat bunga.

Risiko pembiayaan kembali berhubungan dengan likuiditas atau ketersediaan dana yang cukup untuk melunasi pembayaran pokok dan bunga utang yang jatuh tempo dalam waktu yang sama atau berdekatan. Jika dana yang tersedia tidak mencukupi, Pemerintah akan mencari sumber pembiayaan baru untuk melunasi utang sebelumnya. Akibatnya permintaan uang di pasar akan meningkat, dan jika penawaran uang cenderung stabil maka konsekuensinya cost of fund berupa tingkat bunga yang diminta akan naik. Indikator risiko pembiayaan kembali diukur dari durasi portofolio utang, rata-rata utang jatuh tempo (average time to maturity) dan porsi utang jatuh tempo terhadap total utang.

Risiko kesinambungan fiskal berhubungan dengan porsi utang Pemerintah, baik pokok maupun bunga, terhadap APBN. Karena semakin besar anggaran yang dialokasikan untuk pembayaran pokok dan bunga utang, semakin sedikit sisa anggaran yang dapat dialokasikan ke sektor lain yang lebih produktif. Indikator yang digunakan untuk mengukur risiko kesinambungan fiskal adalah rasio utang terhadap PDB, rasio beban bunga terhadap total utang, rasio beban bunga terhadap pendapatan, dan rasio beban bunga terhadap belanja.

\subsection{Teknik Pengukuran dan Analisis Data}

Pengukuran dan analisis risiko dilakukan dengan cara membandingkan capaian indikator risiko terhadap target yang terdapat dalam strategi pengelolaan utang dengan memperhatikan berbagai faktor dan kondisi yang mempengaruhi. Lebih jauh lagi, perbandingan juga dilakukan antara kebijakan manajemen risiko dalam strategi pengelolaan utang pemerintah terhadap pedoman umum yang diatur dalam Peraturan Menteri Keuangan Nomor 190/PMK.09/2008 jo. Peraturan Menteri Keuangan Nomor 12/PMK.09/2016 tentang Penerapan Manajemen Risiko di Lingkungan Kementerian Keuangan dan Guidelines for Public Debt Management yang dirilis oleh International Monetary Fund (IMF) dan World Bank.

\section{HASIL PENELITIAN}

\subsection{Kondisi Perekonomian Indonesia Tahun 2005-2014}

Ekonomi Indonesia pada Tahun 2005 tumbuh di level 5,6 persen. Harga minyak dunia mencapai level tertinggi dalam kurun waktu 25 tahun terakhir yaitu USD 78,22/barrel. Untuk mencegah peningkatan defisit APBN akibat realisasi belanja subsidi BBM yang bertambah drastis, pemerintah kemudian menaikan harga BBM dua kali, pertama pada bulan Maret menjadi Rp2.400,00 dari semula Rp1.810,00 atau naik sekitar 32,6 persen, kemudian pada bulan Oktober kembali dinaikan menjadi Rp4.500,00 atau naik sekitar 87,5 persen. Imbas dari kebijakan tersebut inflasi terdorong naik hingga ke level 18,38 persen pada Bulan November meski kemudian turun ke level 17,11 persen pada Bulan Desember, sehingga untuk mengimbanginya $\mathrm{BI}$ Rate juga mengalami tren kenaikan hingga ke level tertinggi sepanjang sejarah yaitu 12,75 persen pada Bulan Desember. Di sisi lain Rupiah terus melemah sampai ke level Rp12.000,00 per 1 USD pada Bulan Agustus namun ditutup pada Bulan Desember di level Rp9.831,00 per 1 USD dengan rata-rata selama Tahun 2005 Rp9.713,00 per 1 USD. Neraca Pembayaran Indonesia pada tahun ini defisit USD0,4 Miliar sedangkan cadangan devisa tergerus hingga turun ke level USD 34,7 Miliar dari saldo tahun sebelumnya yang mencapai USD 36,3 Miliar.

Kondisi perekonomian Indonesia 2006 masih terimbas krisis tahun sebelumnya, namun pada Semester II beberapa indikator ekonomi makro mulai mengalami perbaikan. PDB tumbuh 5,5 persen, lebih rendah daripada tahun sebelumnya. Inflasi indeks harga konsumen year on year akhir tahun 2006 menunjukan arah perbaikan di level 6,59 persen, oleh karena itu BI Rate juga diturunkan sampai ke level 9,75 persen. Harga minyak dunia tercatat sempat naik ke level USD 86,46/barrel pada Bulan Juli namun kemudian cenderung turun kembali dan ditutup pada level USD 72,70/barrel. Sepanjang Tahun 2006 Rupiah secara stabil mengalami penguatan terhadap USD dengan rata-rata nilai tukar Rupiah ke level Rp9.167,00 per 1 USD, lebih baik dibanding Tahun 2005. Perbaikan juga ditunjukkan oleh kinerja Neraca Pembayaran Indonesia yang kembali surplus pada tahun ini menjadi USD 15,04 Miliar, dimana cadangan devisa juga kembali naik ke level USD 42,59 Miliar.

Gambar 1 PDB Indonesia 2005-2014 (dalam Miliar USD) 


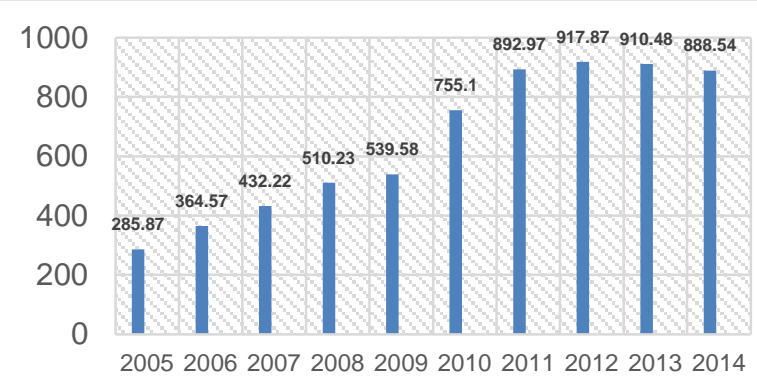

Sumber:

http://www.tradingeconomics.com/indonesia/gdp diakses 21 Januari 2016 Pukul 15.25 WIB

Kondisi perekonomian Indonesia 2007 menunjukkan tanda-tanda perbaikan signifikan. Pertumbuhan PDB 6,32 persen, tertinggi setelah krisis 1998. Neraca pembayaran Indonesia surplus USD 12,5 Miliar, sementara cadangan devisa meningkat mencapai USD 56,9 Miliar. Nilai tukar Rupiah menguat menjadi rata-rata Rp9.140,00 per 1 USD. Laju inflasi sesuai target, mencapai level tertinggi pada Bulan Oktober yaitu 6,88 persen namun membaik pada Bulan Desember dan turun menjadi 6,59 persen, sehingga BI Rate dapat dijaga pada level 8 persen pada akhir tahun. Kondisi eksternal masih memberi tekanan, harga minyak mendekati USD 100/barrel, krisis global yang dimulai dari Subprime Mortgage di AS mulai terasa dampaknya.

\section{Gambar 2 Inflasi Indonesia YoY dan BI Rate 2005-2015}

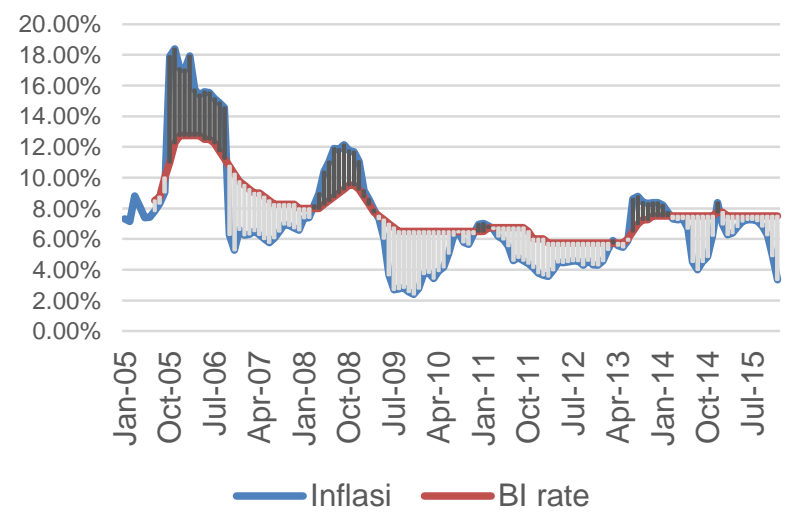

Sumber: diolah dari

http://www.bi.go.id/en/moneter/inflasi/data/Def ault.aspx diakses pada 21 Januari 2016, Pukul 10.17 WIB.

Kondisi perekonomian 2008 kembali mengalami tekanan berat akibat krisis global. Pertumbuhan ekonomi melambat hanya 6,1 persen. Rupiah mengalami tren pelemahan sepanjang tahun hingga mencapai level Rp12.453,00 per 1 USD, namun setelahnya bergerak turun dan ditutup di level Rp11.146,00 per 1 USD. Inflasi melonjak tertinggi pada Bulan
September mencapai 12,14 persen walaupun kemudian turun kembali menjadi 11,06 persen pada akhir tahun. BI Rate kembali dinaikan ke level 9,5 persen pada Bulan November namun turun 25 bps menjadi 9,25 persen pada Bulan Desember. Harga BBM terpaksa dinaikkan pada Mei menjadi Rp6.000,00 atau sekitar 33 persen, namun kemudian diturunkan kembali dua kali menjadi Rp5.000,00 pada Bulan Desember. Memburuknya perekonomian Indonesia juga ditunjukkan oleh posisi Neraca Pembayaran yang kembali defisit USD 1,95 Miliar dan cadangan devisa yang anjlok menjadi hanya USD 51,64 Miliar.

Kondisi perekonomian Indonesia 2009 masih terpengaruh krisis keuangan tahun 2007 dan 2008, namun sudah masuk ke dalam fase pemulihan. PDB tumbuh 4,5 persen, jauh turun dibandingkan tahun-tahun sebelumnya namun justru menjadi pertumbuhan ekonomi tertinggi ketiga di dunia setelah Tiongkok dan India. Inflasi juga tercatat rendah di level 2,78 persen yang menjadi tingkat inflasi terendah selama satu dekade terakhir. Oleh karena itu BI Rate pun menyesuaikan dengan penurunan di level 6,5 persen stabil sampai akhir tahun. Neraca pembayaran berada di posisi surplus USD12,5 Miliar sementara cadangan devisa meningkat di posisi USD 66,1 Miliar. Nilai tukar Rupiah terhadap USD sempat melonjak di level Rp12.075,00 per 1 USD pada Bulan Maret, namun pada akhir tahun dapat membaik hingga di level Rp9.430,00 per 1 USD. Harga BBM juga sempat diturunkan menjadi Rp4.500,00/liter pada Januari.

Kondisi perekonomian Indonesia Tahun 2010 diwarnai berbagai tren positif. Pertumbuhan PDB kembali naik pada level 6,1 persen. Surplus neraca pembayaran naik cukup drastis menjadi USD 30,3 Miliar. Cadangan devisa juga meningkat menjadi USD96,2 Miliar. Rupiah juga menguat di level ratarata tahunan Rp9.081,00 per 1 USD dengan volatilitas yang menurun. Namun imbas dari pertumbuhan yang cukup drastis tersebut, inflasi justru meningkat hingga ke level 6,96 persen, sementara BI Rate dipertahankan di level 6,5 persen sama seperti tahun lalu. Tantangan utama perekonomian Tahun 2010 adalah derasnya aliran dana asing yang masuk ke Indonesia, terutama yang bersifat jangka pendek, karena justru dapat menimbulkan tekanan terhadap stabilitas makro dan rentan terhadap sentimen negatif yang dapat berakibat pada pembalikan modal secara besarbesaran dan tiba-tiba (large and sudden reversal). Selain itu, aliran dana asing yang terlalu besar juga dapat mendorong apresiasi Rupiah melebihi daya dukung fundamentalnya sehingga rentan terhadap risiko koreksi serta dapat mengurangi daya saing ekspor.

Pada 2011 kondisi perekonomian Indonesia menunjukkan stabilitas di tengah berkembangnya 
kembali krisis global yang dipicu memburuknya krisis utang negara-negara di kawasan Eropa. PDB justru tumbuh 6,5 persen, lebih tinggi dibandingkan tahun sebelumnya, bahkan menjadi pertumbuhan tertinggi selama 10 tahun terakhir. Inflasi juga turun dibandingkan tahun lalu pada level yang terkendali 3,79 persen, sehingga BI Rate dapat kembali diturunkan menjadi 6 persen stabil sampai akhir tahun. Neraca pembayaran Indonesia tergerus cukup dalam, namun masih dalam posisi surplus USD11,3 Miliar, sementara cadangan devisa meningkat menjadi USD110,1 Miliar. Secara umum Rupiah mengalami penguatan sepanjang tahun hingga mencapai level terendah Rp8,475,00 per 1 USD pada Agustus, namun setelah itu terkoreksi cukup signifikan kembali ke level stabil Rp9.060,00 per 1 USD pada akhir tahun.

Perekonomian Indonesia pada tahun 2012 masih banyak dipengaruhi kondisi perekonomian global yang tertekan akibat krisis utang Eropa dan perlambatan pertumbuhan ekonomi beberapa negara besar seperti Tiongkok. Namun, PDB Indonesia masih dapat tumbuh cukup tinggi yaitu 6,2 persen meskipun lebih rendah dibandingkan tahun sebelumnya. Inflasi juga berhasil dikendalikan di level 4,3 persen sesuai dengan target 4,5 persen \pm 1 persen. BI Rate turun 25 bps stabil di level 5,75 persen sampai akhir tahun. Neraca pembayaran kembali tergerus sehingga surplus hanya USD 0,21 Miliar, namun cadangan devisa masih meningkat menjadi USD 112,8 Miliar. Rupiah sempat menguat sesaat pada Bulan Februari ke level Rp8.930,00 per 1 USD, namun selanjutnya sepanjang tahun terdepresiasi dan ditutup pada 31 Desember di level Rp9.628,00 per 1 USD.

\section{Gambar 3 Posisi Neraca Pembayaran dan Cadangan Devisa Indonesia 2005-204 (dalam Miliar USD)}

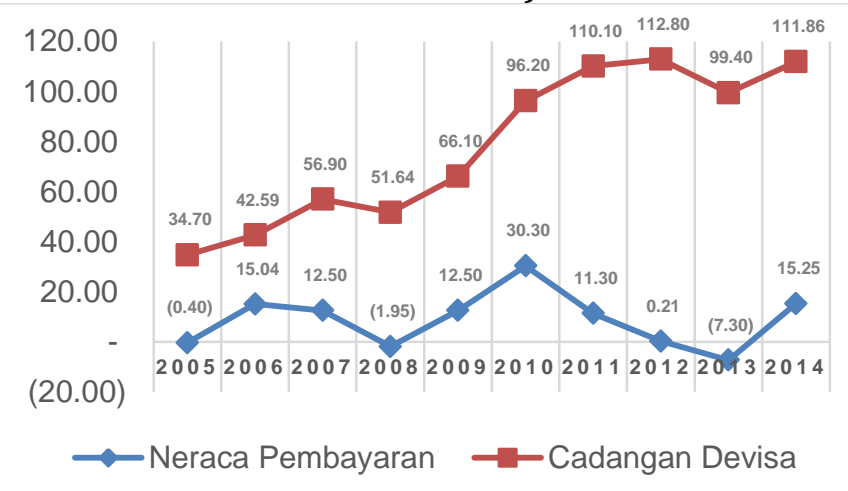

Sumber: diolah dari Laporan Perekonomian Indonesia 2005 s.d. 2014 Bank Indonesia

Tahun 2013 perekonomian Indonesia mengalami banyak tekanan baik internal maupun eksternal. Pertumbuhan PDB melambat dibandingkan tahun lalu, yaitu di level 5,8 persen.
Harga minyak dunia yang kembali naik sejak akhir tahun 2012 hingga menyentuh USD 100/barrel pada awal tahun 2013 memaksa pemerintah menaikan harga BBM menjadi Rp6.500,00/liter untuk mencegah melebarnya defisit APBN. Akibatnya inflasi mengalami tren kenaikan hampir sepanjang tahun, mencapai puncaknya pada Agustus di level 8,79 persen, namun setelahnya berangsur turun mencapai level 8,38 persen pada akhir tahun. BI Rate juga kemudian menyesuaikan dengan naik drastis 175 bps menjadi 7,5 persen. Tren pelemahan Rupiah tahun lalu masih berlanjut pada Tahun 2013. Rupiah terus tertekan sepanjang tahun, sempat mengalami fluktuasi menguat pada pertengahan Oktober, namun selebihnya sampai akhir tahun terus melemah dan ditutup pada level Rp12.144,00 per 1 USD, tertinggi setelah krisis 2008. Neraca pembayaran Indonesia ditutup dalam posisi defisit USD 7,3 Miliar, sementara cadangan devisa juga anjlok menjadi USD 99,4 Miliar.

Pada Tahun 2014, pertumbuhan ekonomi kembali melambat hanya sebesar 5,0 persen, turun dibandingkan tahun sebelumnya. Inflasi sempat membaik dan turun ke level 3,99 persen pada Bulan Agustus, namun setelahnya kembali naik sehingga ditutup di level 8,36 persen pada akhir tahun yang terutama disebabkan dinaikkannya harga BBM menjadi Rp8.500/liter pada Bulan November. Untuk meresponnya, BI Rate kembali disesuaikan naik 25 bps menjadi 7,75 persen. Neraca pembayaran kembali surplus di posisi USD 15,25 Miliar sedangkan cadangan devisa juga kembali tumbuh menjadi USD 111,86 Miliar.

Berdasarkan pembahasan tersebut, terlihat bahwa perekonomian Indonesia banyak dipengaruhi oleh perubahan kondisi perekonomian global. Akibatnya pada periode tersebut terjadi perkembangan risiko pengelolaan utang Pemerintah dan dengan sendirinya juga dibutuhkan penyesuaian strategi untuk mengantisipasinya.

\subsection{Identifikasi dan Analisis Risiko Utang}

\subsubsection{Risiko Nilai Tukar}

Salah satu indikator yang digunakan untuk mengukur fluktuasi nilai tukar Rupiah terhadap mata uang asing adalah volatilitasnya. Volatilitas tersebut menghitung deviasi nilai tukar harian terhadap rata-rata tahunannya (moving average) selama kurun waktu 250 hari. Volatilitas nilai tukar Rupiah terhadap USD selama 2005 s.d. 2014 dapat dilihat pada Gambar 4 yang secara umum bergerak cukup stabil. Lonjakan siginifikan hanya terjadi pada Tahun 2005, 2006 dan 2008 dipengaruhi beberapa faktor fundamental perekonomian dalam negeri dan faktor sentimen global akibat krisis. 


\section{Gambar 4 Volatilitas Tahunan Rupiah terhadap} USD

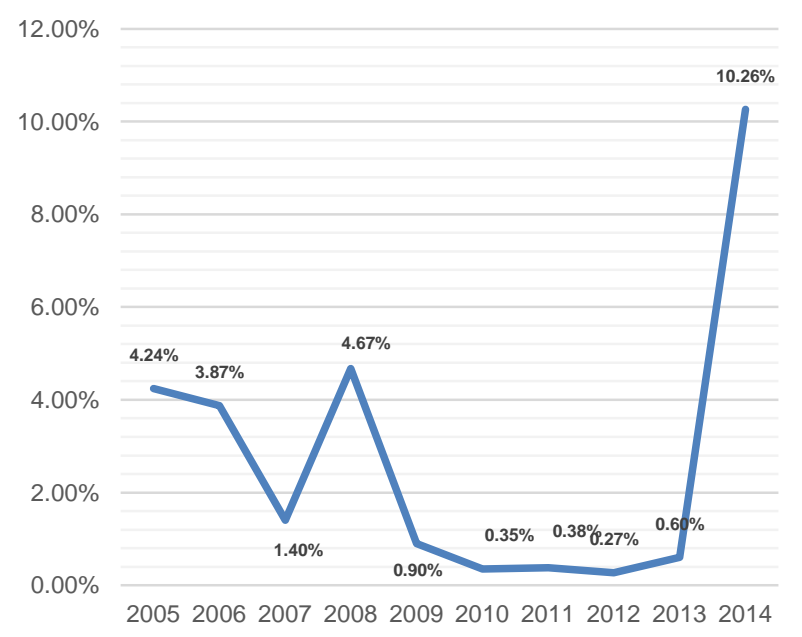

Sumber: diolah dari Laporan Perekonomian Indonesia 2005 s.d. 2014 Bank Indonesia

Beberapa faktor fundamental yang mempengaruhi nilai tukar rupiah selama periode 2005 s.d. 2009 yaitu: (1) Kenaikan harga minyak dunia meningkatkan kebutuhan valas untuk melakukan impor minyak, karena kebutuhan BBM dalam negeri belum dapat dipenuhi oleh produksi dalam negeri sehingga kekurangannya harus dipenuhi dari impor tersebut; (2) Investasi asing di Indonesia masih didominasi oleh investasi portofolio yang bersifat jangka pendek dan sewaktu-waktu dapat kembali ke negara asal (sudden reversal) jika terdapat kebijakan atau sentimen yang mendukung, di sisi lain investasi langsung jangka panjang (Foreign Direct Investment) masih terbatas; (3) Kebijakan moneter ketat dari The Fed dengan menaikan suku bunga acuan AS mendorong investor untuk mengalihkan dananya kembali ke AS; (4) Kebutuhan valas untuk pembayaran utang luar negeri yang cukup tinggi.

Sedangkan faktor sentimen global yang mempengaruhi di antaranya adalah: (1) Lonjakan harga minyak dunia juga mengindikasikan ekspansi perekonomian sehingga mendorong investor untuk cenderung membeli valas, atau memindahkan investasinya dari emerging countries ke developed countries; (2) Krisis subprime mortgage di AS dan krisis utang di Eropa menyebabkan investor cenderung lebih berhatihati dalam menempatkan dananya dan menghindari aset-aset yang dinilai berisiko tinggi, salah satunya aset di emerging countries.

\section{Gambar 5 Portofolio Utang Pemerintah Berdasarkan Mata Uang Utama (dalam Triliun Rupiah)}

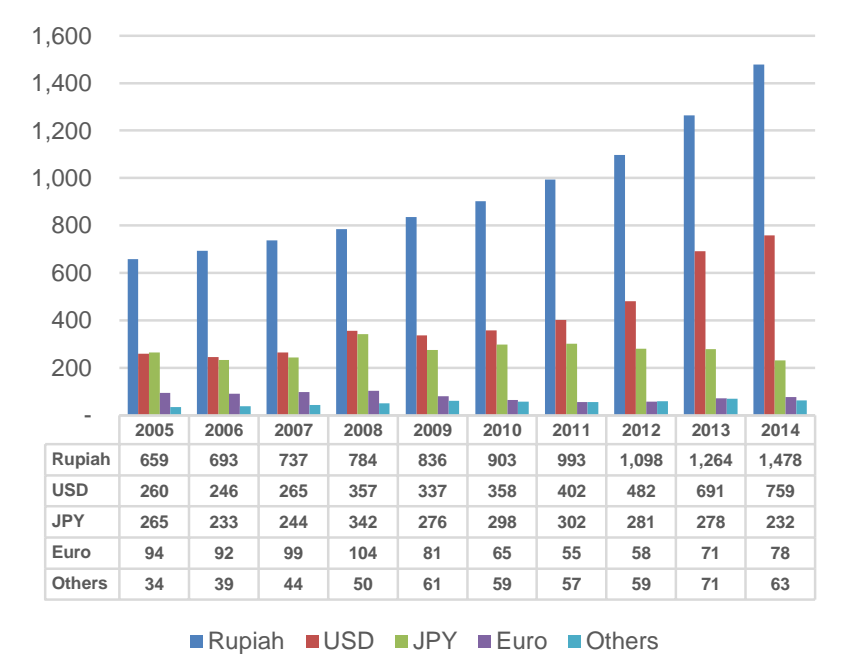

Sumber: diolah dari Profil Utang Pemerintah Pusat, DJPPR Kementerian Keuangan

Porsi utang berdenominasi Rupiah secara konsisten mendominasi dalam 10 tahun terakhir. Adapun utang berdenominasi valas didominasi oleh USD dan JPY. Meskipun kedua mata uang tersebut memiliki volatilitas yang tinggi namun tetap dipertahankan jumlah dan porsinya untuk kebutuhan pelaksanaan Assets and Liabities Management (ALM), dimana penarikan pinjaman luar negeri atau penerbitan SBN valas diprioritaskan dalam mata uang yang sama dengan outstanding utang saat ini sehingga meminimalkan risiko fluktuasi nilai tukar.

Namun yang perlu dicermati dan diwaspadai adalah peningkatan outstanding utang yang tidak disebabkan oleh penerbitan SBN atau penarikan pinjaman baru tetapi karena fluktuasi nilai tukar. Pada Gambar 6 terlihat bahwa pada setiap tahun terjadi perbedaan nilai outstanding utang riil dengan nilai hasil perhitungan net flow utang. Net flow utang dihitung berdasarkan jumlah penerbitan SBN atau pengadaan pinjaman baru dibandingkan dengan pembayaran pokok utang pada tahun yang sama. Selisih terbesar terjadi pada Tahun 2008, 2013 dan 2015 yang berarti pada tahun-tahun tersebut terjadi perubahan kondisi perekonomian domestik dan global yang kemudian secara tidak langsung menyebabkan pelemahan nilai tukar Rupiah yang drastis sehingga menambah nilai outstanding utang. Jika kondisi tersebut terus berlangsung maka outstanding utang akan bertambah tanpa ada peningkatan produktivitas riil. 


\section{Gambar 6 Perbandingan Posisi Utang Valas Riil dan berdasarkan Net Flow (dalam Triliun Rupiah)}

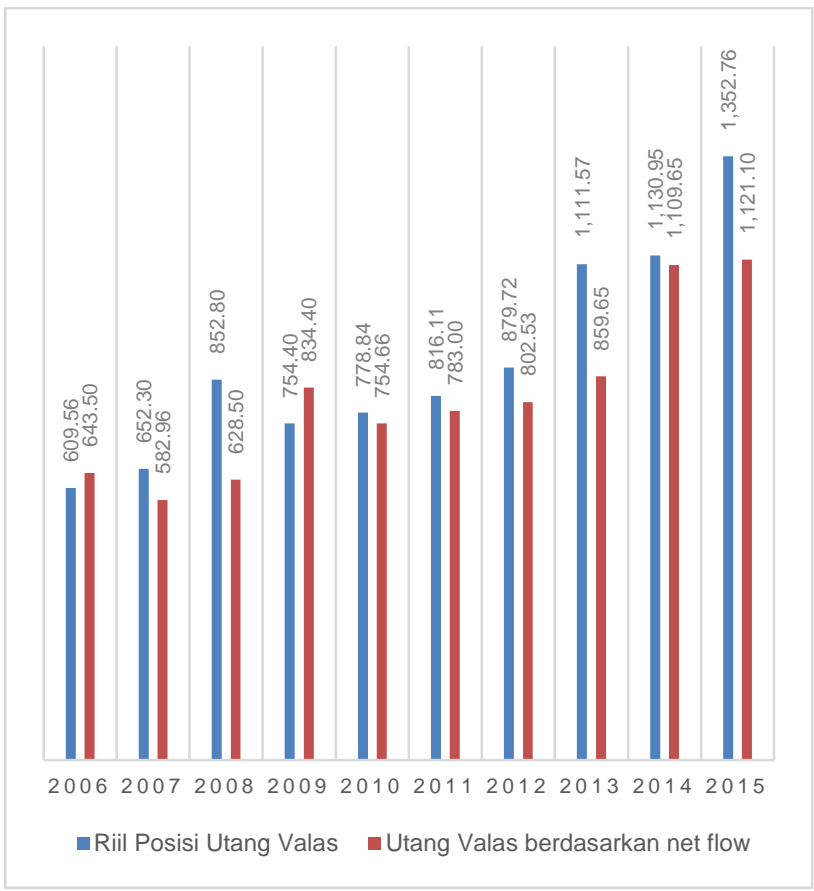

Sumber: diolah dari Profil Utang Pemerintah Pusat, DJPPR Kementerian Keuangan

Kepemilikian asing terhadap SBN domestik juga harus diperhatikan dan diwaspadai. Hal itu karena karakteristik investor dalam negeri yang masih menjadi follower atas langkah yang diambil oleh investor asing. Sehingga pergerakan pada komposisi kepemilikan asing terhadap SBN domestik tersebut dapat mempengaruhi struktur kepemilikan secara keseluruhan. Jika pada titik tertentu investor asing tersebut memutuskan untuk melepaskan seluruh SBN domestik yang dimilikinya dan mengalihkannya ke instrumen investasi lain di luar negeri (reversal), maka secara tidak langsung terjadi pelepasan Rupiah dalam jumlah besar dan pada waktu yang sama terjadi permintaan valas dalam jumlah yang sama besarnya. Kondisi tersebut tentu akan sangat mempengaruhi keseimbangan fluktuasi nilai tukar Rupiah yang pada akhirnya juga akan meningkatkan eksposur utang Pemerintah terhadap perubahan nilai tukar tersebut. Pada periode 2007 s.d. 2015 terjadi penambahan porsi kepemilikan asing atas SBN domestik sebagaimana terlihat dalam Gambar 7 berikut.

\section{Gambar 7 Porsi Kepemilikan Asing atas SBN Domestik}

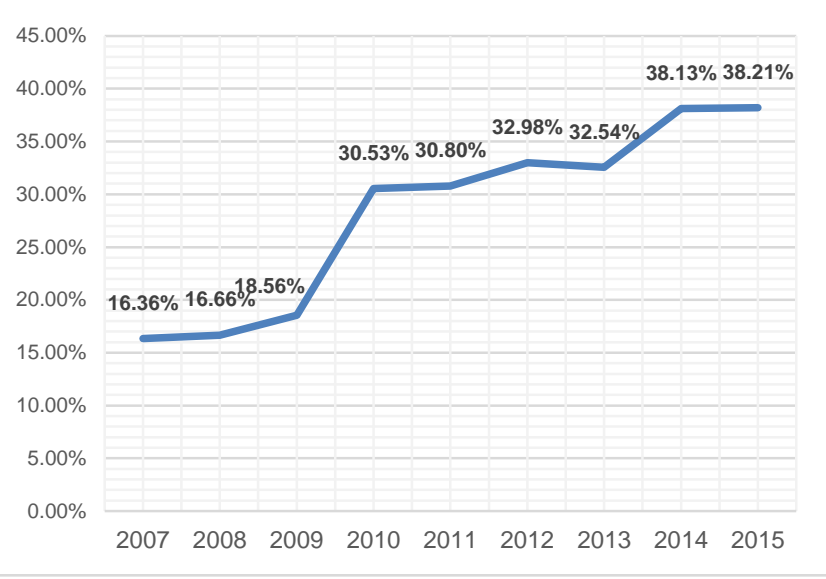

Sumber:

http://www.djppr.kemenkeu.go.id/page/load/29

(diakses 31 Januari 2016, Pukul 22.02 WIB)

Pada Tabel 1 berikut terlihat perkiraan perubahan outstanding utang jika variabel nilai tukar Rupiah terhadap masing-masing valas berubah. Sensitivitas terhadap USD mengalami peningkatan seiring dengan penambahan jumlah utang berdenominasi USD, namun sebaliknya untuk JPY mengalami penurunan sensitivitas yang juga dipengaruhi oleh penurunan utang berdenominasi JPY. Sedangkan perubahan dalam mata uang Euro dan Poundsterling cenderung lebih stabil dari tahun ke tahun. Pada Tahun 2013 penambahan Rp100,00 per 1 USD akan menyebabkan penambahan utang sebesar Rp5,68 Triliun, sedangkan penambahan Rp1,00 per 1 JPY akan menyebabkan penambahan utang sebesar Rp2,38 Triliun.

\section{Tabel 1 Sensitivitas Portofolio Utang terhadap Perubahan Nilai Tukar}

\begin{tabular}{|l|l|r|r|r|r|r|}
\hline Valas & Perubahan & \multicolumn{5}{|c|}{$\begin{array}{c}\text { Perubahan Outstanding Utang } \\
\text { (dalam Triliun Rupiah) }\end{array}$} \\
\cline { 3 - 7 } & & $\mathbf{2 0 0 9}$ & $\mathbf{2 0 1 0}$ & $\mathbf{2 0 1 1}$ & $\mathbf{2 0 1 2}$ & $\mathbf{2 0 1 3}$ \\
\hline USD & 100 Rupiah & 3,58 & 3,96 & 4,37 & 4,98 & 5,68 \\
\hline JPY & 1 Rupiah & 2,71 & 2,69 & 2,59 & 2,50 & 2,38 \\
\hline EUR & 100 Rupiah & 0,59 & 0,54 & 0,47 & 0,45 & 0,42 \\
\hline GBP & 100 Rupiah & 0,05 & 0,05 & 0,04 & - & - \\
\hline
\end{tabular}

Sumber: Laporan Analisis Portofolio dan Risiko Utang, DJPPR Kementerian Keuangan

\subsubsection{Risiko Tingkat Bunga}

Risiko tingkat bunga dipengaruhi oleh dua variabel utama, yaitu tingkat bunga Surat Perbendaharaan Negara (SPN) 3 bulanan, yang menjadi acuan untuk menentukan tingkat bunga SBN domestik variable rate, dan tingkat bunga London Interbank Offered Rate (LIBOR) yang 
menjadi acuan untuk menentukan tingkat bunga pinjaman luar negeri. Tingkat bunga SPN 3 bulanan diperoleh melalui lelang terbuka, sedangkan LIBOR diperoleh melalui rata-rata tingkat bunga pinjaman tanpa agunan dari 18 bank anggota British Bank Association (BBA). Pemerintah tidak secara aktif terlibat dalam penentuan besaran LIBOR, namun tetap mengamati berbagai indikator pasar keuangan global.

Indikator yang pertama adalah US Treasury Bill over Euro Dollar (TED) Spread, yaitu selisih antara tingkat bunga treasury bills AS sebagai acuan risk-free dan LIBOR sebagai acuan tingkat bunga komersial. TED Spread mengukur likuiditas pasar keuangan global karena mencerminkan keyakinan dan ekspektasi investor atas pasar keuangan. Semakin kecil nilai spread menunjukkan keyakinan yang tinggi sehingga investor cenderung meningkatkan investasinya, begitu pula sebaliknya.

\section{Gambar 8 Perkembangan TED Spread Periode 2005-2015 (dalam Bps)}

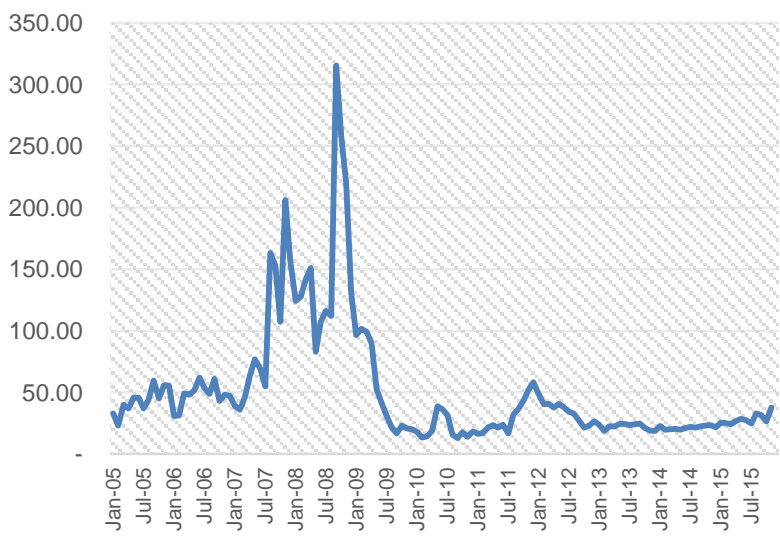

Sumber; http://www.macrotrends.net/1447/tedspread-historical-chart (diakses pada 1 Februari 2016, Pukul 00.03 WIB)

Indikator kedua yang digunakan untuk memantau level risiko tingkat bunga dari SBN yang diterbitkan oleh Pemerintah adalah Credit Default Swap (CDS) rate. CDS merupakan instrumen derivatif pada pasar obligasi yang memberikan jaminan bahwa suatu obligasi akan tetap dibayar bunga dan pokoknya secara tepat jumlah dan tepat waktu meskipun issuer dari obligasi tersebut mengalami default. CDS rate Indonesia menunjukan tingkat keyakinan dan ekspektasi pasar bahwa SBN yang diterbitkan oleh Pemerintah akan dibayar kuponnya tepat waktu dan dilunasi pokoknya ketika jatuh tempo. Semakin rendah CDS rate berarti semakin tinggi keyakinan pasar terhadap SBN Indonesia dan secara tidak langsung merefleksikan tingkat risiko default yang rendah sehingga yield yang diharapkan investor juga cenderung lebih rendah, begitu pula sebaliknya. Pada Gambar 9 terlihat bahwa CDS Indonesia dalam rentang 5 tahun ke depan cenderung lebih tinggi dibandingkan negara-negara peers seperti Brazil, Thailand, dan Turki.

\section{Gambar 9 Pergerakan CDS 5 Years Spread Indonesia, Brazil, Thailand dan Turki}

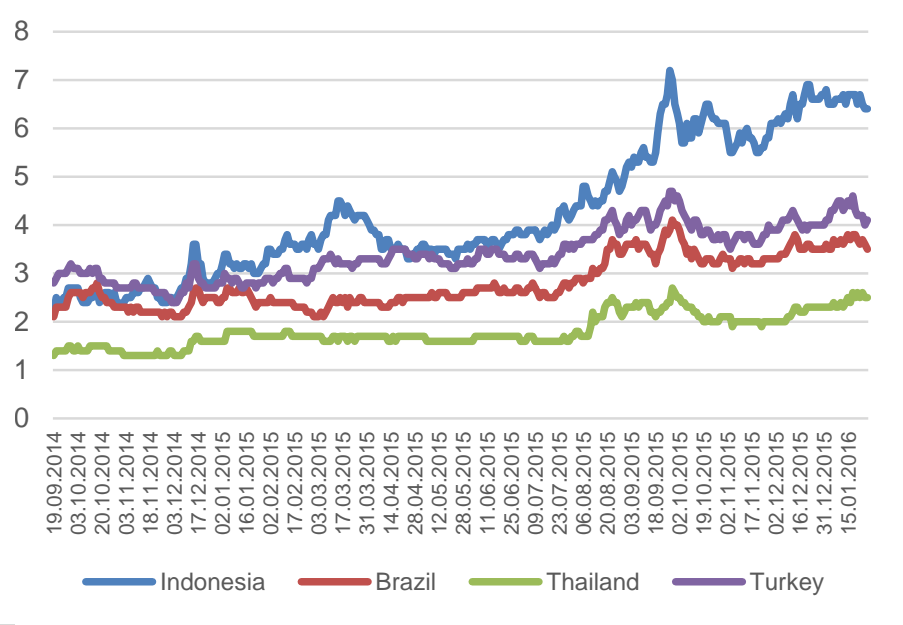

Sumber: Deutsche Bank Research, diakses pada 1 Februari 2016 Pukul 00.21 WIB

Indikator ketiga adalah Sovereign Credit Rating, yaitu opini dari lembaga rating tersebut terkait kemampuan Pemerintah dalam memenuhi kewajiban pembayaran utang secara penuh dan tepat waktu. Informasi tersebut sangat penting bagi investor untuk menentukan tingkat bunga yang diharapkan terkait dengan risiko yang melekat pada SBN sesuai dengan rating-nya. Semakin baik hasil rating menunjukkan tingkat risiko yang lebih rendah, sehingga tingkat bunga yang diharapkan juga menjadi lebih rendah. Pada Tabel 2 berikut terlihat perkembangan sovereign rating Indonesia menurut beberapa lembaga rating Internasional.

Tabel 2 Sovereign Rating Indonesia Tahun 2005-2015

\begin{tabular}{|c|c|c|c|}
\hline Tahun & S\&P & Moody's & Fitch \\
\hline 2005 & B+ & B2 & BB- \\
\hline 2006 & BB- & B1 & BB- \\
\hline 2007 & BB- & Ba3 & BB- \\
\hline 2008 & BB- & Ba3 & BB \\
\hline 2009 & BB- & Ba2 & BB \\
\hline 2010 & BB & Ba2 & BB+ \\
\hline 2011 & BB+ & Ba1 & BBB- \\
\hline 2012 & BB+ & Baa3 & BBB- \\
\hline 2013 & BB+ & Baa3 & BBB- \\
\hline 2014 & BB+ & Baa3 & BBB- \\
\hline 2015 & BB+ & Baa3 & BBB- \\
\hline
\end{tabular}

Sumber: http://www.bi.go.id/en/iru/marketdata/indonesian-sovereign-rating /Defaultaspx diakses pada 1 Februari 2016 Pukul 00.46 WIB 
Dan indikator keempat adalah yield curve yaitu kurva yang menghubungkan titik-titik yield dari SBN becnhmark dalam berbagai periode jatuh tempo, dari satu tahun sampai tiga puluh tahun ke depan. Yield curve mencerminkan ekspektasi pasar atas tingkat risiko dan bunga yang bersedia diterima untuk berinvestasi pada SBN benchmark pada jangka pendek dan jangka panjang. Karena rentang waktunya yang sangat panjang, maka selain untuk mengidentifikasi risiko, yield curve juga dapat digunakan untuk memperkirakan datangnya krisis di masa depan dengan memperhatikan bentuk kurvanya (Harvey, 2011). Dalam kondisi perekonomian normal dan stabil, tingkat bunga SBN benchmark jangka pendek akan lebih rendah daripada jangka panjang, oleh karena itu bentuk kurva akan melengkung ke atas. Namun dalam kondisi krisis keuangan dimana pasar mengalami kekurangan likuiditas, bentuk kurva akan melengkung ke bawah atau terbalik (inverted) karena tingkat bunga SBN benchmark jangka pendek lebih tinggi daripada SBN benchmark jangka panjang. Adapun SBN benchmark dipilih sebagai acuan karena sifatnya yang likuid dan selalu tersedia permintaan dan penawarannya di pasar sekunder, sehingga pergerakannya dianggap merefleksikan pergerakan di pasar SBN secara keseluruhan.

\section{Gambar 10 Posisi Yield Curve Indonesia per 29} Januari 2016

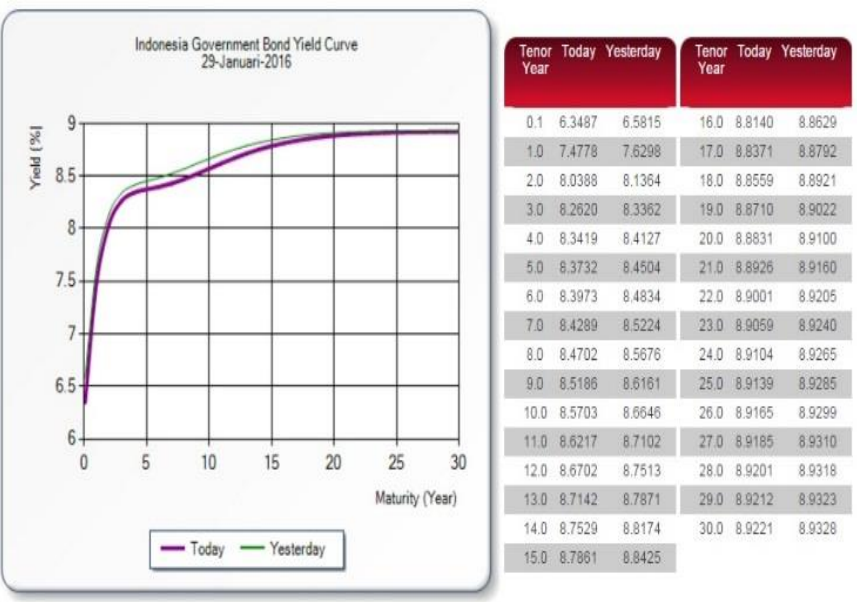

Sumber: Indonesia Bond Pricing Agency, diakses 1 Februari 2016 Pukul 1.26 WIB

Pada Tabel 3 berikut terlihat seberapa besar pengaruh fluktuasi tingkat bunga acuan terhadap beban biaya utang. Kenaikan tingkat bunga SPN 1 bps atau 0,01 persen saja dapat menyebabkan kenaikan beban bunga sebesar Rp12,28 Miliar, sedangkan kenaikan LIBOR 6 bulan 1 bps akan menyebabkan kenaikan beban bunga sebesar Rp20,4 Miliar.

\section{Tabel 3 Sensitivitas Biaya Utang terhadap Perubahan Tingkat Bunga Acuan}

Sumber: Laporan Analisis Portofolio dan Risiko

\begin{tabular}{|c|l|l|l|l|l|l|l|}
\hline \multirow{2}{*}{ No } & \multirow{2}{*}{$\begin{array}{c}\text { Jenis } \\
\text { Bunga }\end{array}$} & \multirow{2}{*}{$\begin{array}{c}\text { Peruba- } \\
\text { han }\end{array}$} & \multicolumn{5}{|c|}{$\begin{array}{c}\text { Perubahan biaya utang } \\
\text { (dalam Miliar Rupiah) }\end{array}$} \\
\cline { 4 - 8 } & & $\mathbf{2 0 0 9}$ & $\mathbf{2 0 1 0}$ & $\mathbf{2 0 1 1}$ & $\mathbf{2 0 1 2}$ & $\mathbf{2 0 1 3}$ \\
\hline 1 & $\begin{array}{l}\text { SBI / } \\
\text { SPN } 3 \\
\text { Month }\end{array}$ & 1 bps & 14,33 & 14,28 & 13,51 & 12.28 & 12,28 \\
\hline 2 & $\begin{array}{l}\text { LIBOR } \\
6 \\
\text { Month }\end{array}$ & 1 bps & 13,35 & 13,52 & 12,65 & 14.73 & 20,40 \\
\hline 3 & Lainnya & 1 bps & 7,47 & 6,22 & - & - & - \\
\hline
\end{tabular}

Utang, DJPPR Kementerian Keuangan

\subsubsection{Risiko Pembiayaan Kembali}

Risiko pembiayaan kembali dapat dilihat dari profil jatuh tempo utang, terutama yang waktunya berdekatan. Penyebab meningkatnya risiko pembiayaan kembali adalah besarnya penerbitan SBN jangka pendek, akibat krisis global yang membuat investor lebih berhati-hati, juga karena belum optimalnya daya serap investor institusi dalam negeri yang memiliki preferensi portofolio jangka panjang seperti dana pensiun dan asuransi. Mayoritas investor dalam negeri adalah perbankan yang memiliki preferensi portofolio jangka pendek untuk kepentingan manajemen kas.

\section{Gambar 11 Perbandingan Profil Jatuh Tempo Utang Periode 2009-2015}

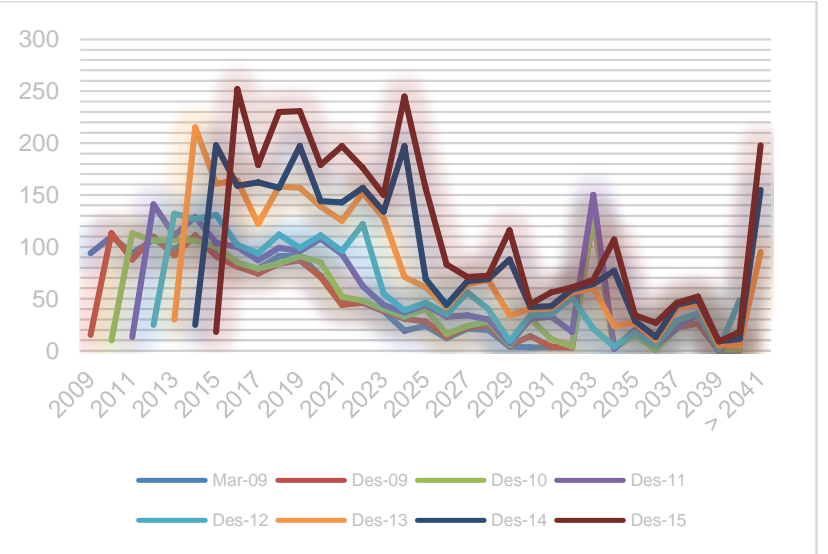

Sumber: Profil Utang Pemerintah Pusat, DJPPR Kemenkeu RI

\subsubsection{Risiko Kesinambungan Fiskal}

Risiko kesinambungan fiskal dipengaruhi sekurang-kurangnya dua faktor, yaitu perubahan kebutuhan pembiayaan dan melesetnya asumsi makroekonomi APBN. Perubahan kebutuhan pembiayaan dapat terjadi salah satunya seperti pada Tahun 2015 ketika target penerimaan pajak tidak terpenuhi, sehingga defisit APBN yang direncanakan hanya 1,9 persen dari PDB naik menjadi 2,58 persen dari PDB. Sedangkan perubahan asumsi makroekonomi seperti ketika pada Tahun 2008 diasumsikan harga minyak dunia 
di level USD 97/barrel, namun ternyata realisasinya mencapai USD 144,78/barrel. Akibatnya realisasi belanja subsidi naik hampir dua kali lipat menjadi Rp275,3 Triliun dibandingkan tahun sebelumnya Rp150,2 Triliun. Selain itu asumsi target pertumbuhan ekonomi juga beberapa kali tidak tercapai sepanjang periode 2005 s.d. 2014.

\section{Tabel 4 Target dan Capaian Pertumbuhan} Ekonomi

\begin{tabular}{|c|c|c|c|}
\hline Tahun & Target & Realisasi & $\%$ \\
\hline 2005 & 5,4 & 5,6 & $103,70 \%$ \\
\hline 2006 & 5,8 & 5,5 & $94,83 \%$ \\
\hline 2007 & 6,3 & 6,32 & $100,32 \%$ \\
\hline 2008 & 6,8 & 6,1 & $89,71 \%$ \\
\hline 2009 & 6,0 & 4,5 & $75,00 \%$ \\
\hline 2010 & 5,5 & 6,1 & $110,91 \%$ \\
\hline 2011 & 6,5 & 6,5 & $100,00 \%$ \\
\hline 2012 & 6,7 & 6,2 & $92,54 \%$ \\
\hline 2013 & 6,2 & 5,8 & $93,55 \%$ \\
\hline 2014 & 6,0 & 5,0 & $83,33 \%$ \\
\hline
\end{tabular}

Sumber: LKPP dan Laporan Perekonomian Indonesia BI

\subsection{Kebijakan Manajemen Risiko}

\subsubsection{Penerbitan Utang Baru}

Untuk penerbitan/pengadaan utang baru, strategi yang dilakukan adalah: (1) kebijakan negative net flow untuk pinjaman luar negeri dan maksimal 20 persen dari gross total SBN untuk penerbitan SBN valas; (2) penerbitan/ pengadaan utang berdenominasi valas diutamakan pada mata uang yang volatilitasnya relatif rendah dan mata uang yang sama untuk pembayaran kewajiban utang yang jatuh tempo dalam rangka natural hedging; (3) penerbitan/ pengadaan utang baru diutamakan yang menggunakan tingkat bunga tetap, utang dengan tingat bunga mengambang dimungkinkan sebagai penyeimbang portofolio, namun hanya dalam kondisi perekonomian stabil; (3) penerbitan/ pengadaan utang baru diutamakan untuk yang bertenor jangka menengah dan jangka panjang. Untuk menentukan durasi SBN, dapat melakukan pemetaan profil portofolio investor melalui survey dan reviu statistik riwayat transaksi untuk menentukan karakteristik dan durasi yang diminati; dan (4) melakukan penerbitan SBN di awal tahun untuk memenuhi target kebutuhan pembiayaan dan mengantisipasi daya serap pasar yang rendah pada semester II tahun anggaran.

Pelaksanaan strategi front loading harus dilakukan dengan hati-hati dan terukur dengan memperhatikan kondisi kas negara, kondisi pasar keuangan dan rencana kebijakan fiskal sehingga dapat mendorong pengembangan pasar SBN domestik. Kebutuhan kas pada awal tahun cenderung masih rendah karena realisasi anggaran yang belum optimal, sehingga ada potensi timbul idle cash yang berakibat pada opportunity cost. Kemudian terkait dengan daya serap pasar SBN domestik yang masih terbatas, sehingga penerbitan SBN yang terlalu besar di awal tahun berpotensi akan diserap oleh investor asing yang artinya akan meningkatkan porsi kepemilikan asing atas SBN domestik.

\subsubsection{Buyback}

Buyback merupakan strategi pengelolaan utang berupa pembelian kembali SBN secara tunai yang betujuan untuk stabilisasi pasar, pengelolaan portofolio utang dan mengurangi outstanding utang yang diterbitkan dengan tingkat bunga tinggi. Stabilisasi pasar dilakukan jika terjadi pelepasan SBN dalam volume yang besar pada waktu yang berdekatan, sehingga untuk menghindari jatuhnya harga SBN secara tidak terkendali dan menjaga kepercayaan investor terhadap SBN maka dilakukan buyback. Sedangkan pengelolaan portofolio utang dilakukan untuk menjaga keseimbangan portofolio dan risiko utang akibat penerbitan SBN dengan tingkat bunga yang tinggi. Pada periode 2003-2015 total transaksi buyback mencapai Rp41,15 Triliun.

Tabel 5 Pelaksanaan Buyback Periode 20032015

\begin{tabular}{|c|c|l|r|}
\hline Tahun & $\begin{array}{c}\text { Frekuensi } \\
\text { (Lelang \& } \\
\text { Transaksi } \\
\text { Langsung) }\end{array}$ & $\begin{array}{c}\text { Tenor yang Dibeli } \\
\text { Kembali }\end{array}$ & $\begin{array}{c}\text { Vol. Dibeli } \\
\text { Kembali } \\
\text { (Miliar } \\
\text { Rupiah) }\end{array}$ \\
\hline 2003 & 2 & 1 s.d. 3 Tahun & 8.127 \\
\hline 2004 & 1 & 3 s.d. 5 Tahun & 1.962 \\
\hline 2005 & 4 & $<1$ Tahun s.d. 4 Tahun & 5.158 \\
\hline 2007 & 2 & $<1$ Tahun s.d. 5 Tahun & 2.859 \\
\hline 2008 & 3 & $<1$ Tahun s.d. 19 Tahun & 2.375 \\
\hline 2009 & 2 & $<1$ Tahun & 8.528 \\
\hline 2010 & 13 & $<1$ Tahun s.d. 4 Tahun & 3.201 \\
\hline 2011 & 10 & $<1$ Tahun s.d. 20 Tahun & 3.500 \\
\hline 2012 & 6 & $<1$ Tahun s.d. 5 Tahun & 1.138 \\
\hline 2013 & 5 & 3 Tahun s.d. 25 Tahun & 1.551 \\
\hline 2014 & 3 & s.d. 15 Tahun & 1.351 \\
\hline 2015 & 3 & $<1$ Tahun s.d. 4 Tahun & 1.401 \\
\hline & \multicolumn{2}{|l|}{ Total } \\
\hline
\end{tabular}

Sumber: Profil Utang Pemerintah Pusat, DJPPR Kementerian Keuangan

\subsubsection{Debt Switch}

Debt switch merupakan bagian dari strategi pengelolaan utang yang bertujuan untuk mengurangi risiko pembiayaan kembali dengan cara menarik SBN dengan tenor yang lebih pendek kemudian menukarnya dengan SBN baru yang memiliki tenor yang lebih panjang. Dengan kata lain, switch pada dasarnya adalah sama dengan buyback namun instrumen yang digunakan bukan berupa uang tunai melainkan dengan SBN baru. Dampak dari pelaksanaan switch tersebut adalah peningkatan rata-rata jatuh tempo utang dengan rentang yang lebih panjang, sehingga diharapkan akan mengurangi beban kewajiban pembayaran bunga dan pokok utang dalam satu titik waktu. 
Yang harus diperhatikan dalam perencanaan pelaksanaan debt switch adalah minat para pemegang SBN untuk menukar dengan SBN baru yang tenor nya lebih panjang. Sebab sebagian investor membeli SBN menyesuaikan dengan portofolio investasi dan kebutuhan likuiditasnya. Jika portofolio investor tersebut membutuhkan likuiditas jangka pendek, tentu akan menghindari switch ke SBN jangka panjang. Selain itu kondisi perekonomian juga dapat mempengaruhi minat investor untuk melakukan switch. Dalam kondisi krisis dimana terjadi kekurangan likuiditas investor cenderung menghindari risiko dan mengutamakan likuiditas jangka pendek, tawaran switch akan kurang diminati. Pada periode 20052015 total transaksi debt switch mencapai Rp87,5 Triliun.

Tabel 6 Pelaksanaan Debt Switch Periode 2005-2015

\begin{tabular}{|c|c|c|c|c|}
\hline Tahun & $\begin{array}{c}\text { Freku } \\
\text { ensi } \\
\text { Lelang }\end{array}$ & $\begin{array}{l}\text { Tenor yang } \\
\text { Ditukar }\end{array}$ & $\begin{array}{l}\text { Tenor Seri } \\
\text { Penukar }\end{array}$ & $\begin{array}{c}\text { Vol. } \\
\text { Yang } \\
\text { Diterima } \\
\text { (Miliar } \\
\text { Rupiah) } \\
\end{array}$ \\
\hline 2005 & 1 & $<1$ s.d. 4 Tahun & 15 Tahun & 5.673 \\
\hline 2006 & 12 & $<1$ s.d. 5 Tahun & $\begin{array}{l}5 \text { s.d. } 19 \\
\text { Tahun }\end{array}$ & 31.179 \\
\hline 2007 & 9 & $<1$ s.d. 6 Tahun & $\begin{array}{l}11 \text { s.d. } 20 \\
\text { Tahun }\end{array}$ & 15.782 \\
\hline 2008 & 2 & $<1$ s.d. 4 Tahun & $\begin{array}{l}14 \text { s.d. } 15 \\
\text { Tahun }\end{array}$ & 4.571 \\
\hline 2009 & 6 & $<1$ s.d. 5 Tahun & $\begin{array}{l}12 \text { s.d. } 15 \\
\text { Tahun }\end{array}$ & 2.938 \\
\hline 2010 & 6 & $<1$ s.d. 8 Tahun & $\begin{array}{l}10 \text { s.d. } 21 \\
\text { Tahun }\end{array}$ & 3.920 \\
\hline 2011 & 4 & $<1$ s.d. 4 Tahun & 15 Tahun & 664 \\
\hline 2012 & 4 & $<1$ s.d. 5 Tahun & $\begin{array}{l}10 \text { s.d. } 15 \\
\text { Tahun }\end{array}$ & 11.859 \\
\hline 2013 & 5 & $<1$ s.d. 9 Tahun & $\begin{array}{l}5 \text { s.d. } 15 \\
\text { Tahun }\end{array}$ & 1.976 \\
\hline 2014 & 4 & $<1$ s.d. 5 Tahun & $\begin{array}{l}5 \text { s.d. } 20 \\
\text { Tahun }\end{array}$ & 5.944 \\
\hline 2015 & 2 & $<1$ s.d. 4 Tahun & $\begin{array}{l}10 \text { s.d. } 20 \\
\text { Tahun }\end{array}$ & 3.005 \\
\hline \multicolumn{4}{|c|}{ Total } & 87,511 \\
\hline
\end{tabular}

Sumber: Profil Utang Pemerintah Pusat, DJPPR Kementerian Keuangan

\subsubsection{Debt Swap}

Swap merupakan strategi pengelolaan utang yang bertujuan untuk mengurangi total outstanding pinjaman. Pengurangan pinjaman tersebut dilakukan tidak serta merta melalui penghapusan pinjaman, melainkan dalam bentuk pengalihan kewajiban pembayaran pinjaman tersebut menjadi hibah untuk proyek di bidang yang menjadi prioritas dari negara debitur seperti pendidikan, kesehatan, pemberantasan kemiskinan, dan konservasi lingkungan. Besaran tingkat utang yang dialihkan bervariasi tergantung term yang disepakati dan tertuang dalam perjanjian pinjaman sebagaimana diatur dalam The Paris Club.
Pemerintah Indonesia telah beberapa kali melakukan debt swap untuk mengurangi outstanding utang. Untuk itu Pemerintah harus menyediakan anggaran dengan rentang antara 50 s.d. 100 persen dari nilai pinjaman untuk dialihkan ke berbagai program dan kegiatan Pemerintah yang lebih prioritas. Beberapa Negara yang menyepakati adanya swap dalam perjanjian pinjaman di antaranya adalah Jerman, Italia, Amerika Serikat dan Australia.

Tabel 7 Posisi Swap Utang Pemerintah Indonesia Tahun 2015

\begin{tabular}{|c|c|c|c|c|}
\hline \multirow[t]{2}{*}{ Negara } & \multirow[t]{2}{*}{ Debt Swap } & \multirow{2}{*}{$\begin{array}{c}\text { Nilai } \\
\text { Proyek }\end{array}$} & \multicolumn{2}{|c|}{ Pembatalan } \\
\hline & & & Komitmen & Realisasi \\
\hline Jerman & $\begin{array}{l}\text { Debt Swap } \\
I-\text { VII }\end{array}$ & $\begin{array}{l}\text { EUR } \\
81,3 \text { Juta }\end{array}$ & $\begin{array}{l}\text { EUR 162,4 } \\
\text { Juta }\end{array}$ & $\begin{array}{l}\text { EUR 149,6 } \\
\text { Juta }\end{array}$ \\
\hline Italia & Debt Swap I & $\begin{array}{l}\text { EUR 5,7 } \\
\text { Juta }\end{array}$ & $\begin{array}{l}\text { EUR 5,7 } \\
\text { Juta }\end{array}$ & $\begin{array}{l}\text { EUR 5,7 } \\
\text { Juta }\end{array}$ \\
\hline AS & $\begin{array}{l}\text { Debt } \\
\text { Development } \\
\text { Swap }\end{array}$ & $\begin{array}{l}\text { USD } \\
56,4 \text { Juta }\end{array}$ & $\begin{array}{l}\text { USD 72,1 } \\
\text { Juta }\end{array}$ & $\begin{array}{l}\text { USD } 67,8 \\
\text { Juta }\end{array}$ \\
\hline Australia & Debt Swap & $\begin{array}{l}\text { AUD } \\
37,5 \text { Juta }\end{array}$ & $\begin{array}{l}\text { AUD } 75 \\
\text { Juta }\end{array}$ & $\begin{array}{l}\text { AUD 38,7 } \\
\text { Juta }\end{array}$ \\
\hline \multicolumn{2}{|c|}{$\begin{array}{c}\text { Total Ekuivalen Juta } \\
\text { USD }\end{array}$} & $\begin{array}{l}\text { USD } \\
175,4 \\
\text { Juta }\end{array}$ & $\begin{array}{l}\text { USD 303,7 } \\
\text { Juta }\end{array}$ & $\begin{array}{l}\text { USD 259,8 } \\
\text { Juta }\end{array}$ \\
\hline
\end{tabular}

Sumber: Profil Utang Pemerintah Pusat, DJPPR Kementerian Keuangan

Debt Swap antara Indonesia dan Jerman dilakukan dalam 6 fase yang terdiri dari bantuan untuk pendidikan dasar pada Tahun 2002, bantuan untuk pendidikan menengah pada Tahun 2002, bantuan kredit untuk usaha kecil dan menengah (UKM) pada Tahun 2006 , penguatan perlindungan kawasan taman nasional pada Tahun 2006, rekonstruksi dan rehabilitasi bencana gempa di Daerah Istimewa Yogyakarta pada Tahun 2006, pemberantasan HIV AIDS, Tuberculosis dan Malaria, dan terakhir bantuan pendidikan berupa beasiswa program doktoral di Jerman pada Tahun 2011. Sedangkan Italia, debt swap dialokasikan untuk rekonstruksi dan rehabilitasi korban bencana tsunami Aceh pada Tahun 2005. Selanjutnya Amerika Serikat menyepakati debt swap dialokasikan dalam tiga fase yaitu untuk konservasi hutan di Sumatera pada Tahun 2009, konservasi hutan di Kalimantan pada Tahun 2011 dan perlindungan satwa langka di area Sumatera pada Tahun 2014. Kemudian Australia juga menyepakati debt swap dialokasikan untuk program pemberantasan tuberculosis pada Tahun 2010.

\subsubsection{Hedging}

Pelaksanaan lindung nilai atau hedging telah diatur dalam Peraturan Menteri Keuangan Nomor 12/PMK.08/2013 tentang Transaksi Lindung Nilai dalam Pengelolaan Utang Pemerintah. Pada PMK tersebut Pemerintah dimungkinkan untuk melakukan transaksi lindung nilai yang bertujuan 
untuk mewujudkan struktur portofolio yang optimal dan mengendalikan fluktuasi pembayaran kewajiban utang pemerintah akibat fluktuasi nilai tukar dan/atau tingkat bunga dalam jangka waktu tertentu, namun tidak dimaksudkan untuk tindakan spekulasi dalam rangka memperoleh keuntungan. Dalam PMK tersebut juga telah disebutkan bahwa biaya-biaya yang timbul terkait dengan transaksi lindung nilai menjadi beban APBN dan tidak dianggap sebagai kerugian negara.

Hedging dapat dilakukan dengan dua pendekatan, yaitu natural hedging dan financial hedging. Pendekatan yang pertama merupakan bentuk lindung nilai yang dilakukan secara alami melalui mekanisme saling write-off antara kewajiban dan pendapatan dalam valas yang sama. Sedangkan pendekatan yang kedua membutuhkan instrumen derivatif untuk melaksanakannya seperti future contract hedge, forward contract hedge, currency option hedge, dan currency swap.

Untuk currency swap, sampai saat ini Indonesia telah melakukan kerjasama dengan berbagai negara, terutama di kawasan Asia Pasifik, dalam melakukan swap. Adapun negara-negara tersebut adalah: (1) Jepang, disepakati pada Bulan Desember 2013, dengan nilai swap USD 22,76 Miliar; (2) Korea Selatan, disepakati pada Bulan Maret 2014, dengan nilai swap KRW 10,7 Triliun atau setara Rp115 Triliun; (3) Republik Rakyat Tiongkok, disepakati pada Bulan November 2015, dengan nilai swap CNY 130 Miliar atau setara dengan USD 20 Miliar; dan (4) Australia, disepakati pada Bulan Desember 2015, dengan nilai swap Rp100 Triliun atau sekitar USD 7,1 Miliar.

Namun sampai dengan Tahun 2015, hedging atas utang pemerintah menggunakan instrumen derivatif lainnya belum dapat dilaksanakan karena beberapa pertimbangan. Pertimbangan tersebut di antaranya belum adanya definisi dan batasan yang jelas tentang biaya apa saja yang dapat ditanggung oleh APBN dan tidak dianggap sebagai kerugian negara, misalnya biaya konsultan hukum untuk menyelesaikan perselisihan dengan pihak counterparty atau investor di luar negeri. Kemudian juga belum ada patokan pada level nilai tukar berapa Pemerintah diperbolehkan untuk melakukan hedging. Mekanisme penganggaran biaya untuk pelaksanaan hedging juga belum diatur lebih lanjut. Dan yang terakhir, terkait Standar Akuntansi Pemerintah yang belum mengakomodasi pencatatan akuntansi untuk transaksi derivatif termasuk hedging.

Oleh karena itu untuk saat ini, yang paling mungkin dilakukan dalam rangka lindung nilai selain currency swap adalah natural hedging, yaitu mencocokkan kebutuhan valas untuk pembayaran kewajiban utang dengan pendapatan atau penerbitan utang baru dalam valas yang sama. Dengan begitu fluktuasi nilai tukar rupiah terhadap valas tersebut tidak mempengaruhi beban kewajiban utang yang harus dibayar Pemerintah.

\subsubsection{Asset-liability Management}

Asset-liability Management (ALM) merupakan sebuah mekanisme yang dilakukan untuk menghadapi risiko yang timbul akibat ketidakcocokan (mismatch) antara aset dan kewajiban yang dikelola oleh suatu institusi keuangan, yang dalam konteks ini adalah Kementerian Keuangan. Dibandingkan dengan fungsi treasury yang memiliki perspektif waktu jangka pendek di bawah satu tahun, ALM cenderung memiliki persepektif waktu jangka menengah dan jangka panjang. Oleh karena itu dapat dikatakan juga bahwa ALM merupakan kombinasi dari pelaksanaan manajemen risiko dan manajemen strategis.

Dalam definisi dan ruang lingkup yang lebih luas, ALM sebenarnya meliputi pengelolaan risiko likuiditas, risiko tingkat bunga, risiko nilai tukar. Namun dalam pelaksanaannya ALM pada Pemerintah Indonesia masih terbatas dan berfokus pada pengelolaan likuiditas. Pengelolaan likuiditas tersebut secara sederhana dilakukan dengan membandingkan antara kebutuhan kas untuk belanja Pemerintah dengan pendapatan yang dimiliki baik yang bersumber dari pajak maupun bukan pajak. Jika diketahui bahwa pendapatan yang tersedia tidak mampu memenuhi kebutuhan kas tepat waktu maka dilakukan pembiayaan terutama melalui utang.

Sebagai bentuk formal pelaksanaan ALM, telah dibentuk Komite Pengelolaan Aset dan Liabilitas pada Bulan Februari 2013 yang dipimpin oleh Menteri Keuangan dan Wakil Menteri Keuangan, serta beranggotakan beberapa pejabat eselon 1 di lingkungan Kementerian Keuangan yaitu Dirjen Pengelolaan Pembiayaan dan Risiko sebagai Sekretaris, dan Sekjen Kementerian Keuangan, Kepala BKF, Staf Ahli, Dirjen Perbendaharaan, Dirjen Anggaran, Dirjen Pajak, Dirjen Bea dan Cukai, Dirjen Perimbangan Keuangan dan Dirjen Kekayaan Negara sebagai anggota. Dalam melaksanakan tugasnya Komite ALM melakukan pertemuan rutin setidaknya satu kali dalam sebulan, namun dapat menjadi lebih sering menyesuaikan dengan permintaan Menteri Keuangan dan perkembangan kondisi keuangan negara, terutama pada setiap akhir tahun anggaran. Secara khusus Komite ALM akan menelaah: gambaran ekonomi dan pasar, perkiraan penerimaan, perkiraan pengeluaran, perkiraan kas dan pembiayaan, penilaian risiko terhadap neraca dan kegiatan anggaran, penilaian kebutuhan kas dan pembiayaan baru di masa 
mendatang dan rekomendasi perubahan kebijakan jika diperlukan.

\subsubsection{Crisis Management Protocol dan Bond Stabilization Framework}

Untuk mengantisipasi krisis di pasar SBN, yang berupa pelepasan SBN secara masif dalam waktu yang singkat sehingga menyebabkan harga SBN menurun secara signifikan, pemerintah menyusun Crisis Management Protocol (CMP) SUN. Protokol tersebut diatur dalam Keputusan Dirjen Pengelolaan Utang Nomor 4/PU/2014 tentang Indeks Protokol Manajemen Krisis Pasar SBN dan Indikator Pencabutan Level Kondisi Pasar SBN. Krisis pada pasar SUN dapat dipicu oleh beberapa faktor, diantaranya keluarnya investor asing (nonresidence) atau penjualan oleh investor domestik karena adanya perkembangan situasi ekononomi dan pasar baik di dalam negeri maupun di luar negeri.

CMP berisi langkah-langkah penanganan krisis yang mengacu pada dua indikator, yaitu indikator utama dan indikator sekunder. Indikator utama merupakan harga SUN seri benchmark, sementara indikator sekunder merupakan kombinasi dari pergerakan IHSG, fluktuasi nilai tukar Rupiah terhadap USD dan porsi kepemilikan asing. Kedua indikator tersebut dimonitor setiap hari untuk memastikan kondisi pasar SUN masih normal atau mulai menuju krisis. Kombinasi hasil pantauan kedua indikator akan dikategorikan dalam tiga fase: (1) fase waspada, jika harga dua seri benchmark SUN turun sebesar 200 basis points (bps) dalam satu hari, atau 500 bps dalam tiga hari; (2) fase siaga, jika harga dua seri benchmark SUN turun sebesar 300 bps dalam satu hari atau 600 bps dalam tiga hari; (3) fase krisis, jika harga dua seri benchmark SUN turun sebesar 600 bps dalam satu hari atau 1.000 bps dalam tiga hari.

Langkah-langkah yang diambil jika telah memasuki fase waspada adalah melakukan diseminasi informasi dan komunikasi intensif dengan pelaku pasar yang dibarengi dengan buyback dan penyesuaian instrumen penerbitan dengan demand yang ada. Kemudian jika situasi telah berkembang menjadi fase siaga, maka langkah yang diambil adalah melakukan buyback dan pemberhentian penerbitan di pasar perdana. Sedangkan jika krisis telah terjadi maka diperlukan sebuah paket kebijakan untuk menyelamatkan pasar keuangan.

Sementara Bond Stabilization Framework (BSF) merupakan kerangka memuat mekanisme koordinasi unit-unit terkait di lingkungan Kementerian Keuangan dan beberapa Badan Usaha Milik Negara (BUMN) yang bergerak di bidang keuangan di bawah koordinasi Kementerian Negara BUMN, dalam melakukan pembelian SBN untuk stabilisasi pasar SBN. BSF merupakan bentuk tindak lanjut dari pelaksanaan CMP yang mengidentifikasi level krisis yang sedang dan akan tejadi. BSF diatur dalam Keputusan Menteri Keuangan Nomor 175/KMK/08/2011 tentang Mekanisme Koordinasi Pembelian SBN Dalam Rangka Stabilisasi Pasar SBN di Lingkungan Kementerian Keuangan. Dalam kondisi pasar normal, buyback SBN akan menggunakan anggaran yang sudah dianggarkan pada DJPPR. Sementara itu pada kondisi waspada, Pemerintah dapat mulai memberdayakan BUMN dan BPJS untuk membantu melakukan buyback. Sementara ketika sudah memasuki level siaga, DJPB dapat mulai menggunakan dana Kas Umum Negara (KUN) untuk melakukan buyback. Dan yang terakhir, ketika sudah memasuki fase krisis, maka dana Saldo Anggaran Lebih (SAL) juga dapat digunakan untuk buyback.

\subsection{Capaian Target Indikator Risiko}

Dampak dari telah dilakukannya berbagai langkah pengelolaan risiko oleh Unit Pengelola Utang Pemerintah dapat dilihat dari capaian atas indikator risiko portofolio yang telah ditargetkan dalam Strategi Pengelolaan Utang baik jangka menengah maupun tahunan. Indikator-indikator tersebut telah dikelompokkan berdasarkan masing-masing jenis risiko yang dihadapi. Capaian atas target indikator tersebut menggambarkan seberapa jauh strategi yang telah dilakukan oleh Unit Pengelola Utang Pemerintah dalam mengelola dan mengantisipasi risiko-risiko yang timbul dalam pengelolaan utang.

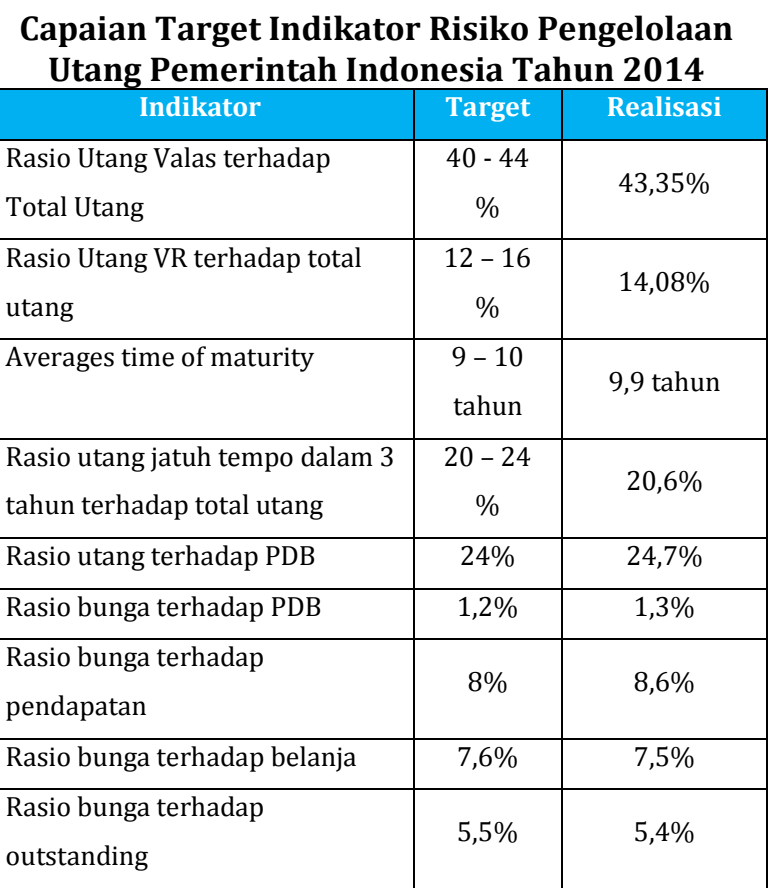

Sumber: Strategi Pengelolaan Utang Pemerintah Indonesia, DJPPR Kementerian Keuangan RI 


\section{KESIMPULAN DAN SARAN}

\subsection{Kesimpulan}

Berdasarkan pembahasan sebelumnya, maka dapat disimpulkan beberapa hal berikut:

Risiko yang dihadapi Pemerintah dalam mengelola utang di antaranya adalah Risiko Nilai Tukar, Risiko Tingkat Bunga, Risiko Pembiayaan Kembali dan Risiko Kesinambungan Fiskal. Beberapa faktor yang memengaruhi indikator risiko tersebut secara umum adalah merupakan indikator perekonomian makro, seperti pertumbuhan ekonomi, harga minyak dunia, tingkat inflasi, bunga acuan $\mathrm{BI}$, saldo neraca pembayaran dan cadangan devisa. Namun secara lebih spesifik, untuk risiko nilai tukar sangat dipengaruhi oleh beberapa faktor seperti volatilitas rupiah terhadap mata uang asing khususnya yang berdenominasi sama dengan pinjaman Pemerintah dan tingkat kepemilikan asing atas SBN domestik. Sedangkan risiko tingkat bunga dipengaruhi beberapa indikator seperti tingkat bunga SPN 3 bulanan, tingkat bunga London Interbank Offered Rate (LIBOR), Treasury Bill over Euro Dollars (TED) Spread, Credit Default Swap, dan Yield Curve. Selanjutnya untuk risiko pembiayaan kembali, faktor yang mempengaruhi adalah jumlah penerbitan SBN jangka pendek dengan waktu jatuh tempo yang relatif singkat, dan daya serap investor institusi khususnya dalam negeri terhadap SBN yang terbitkan oleh Pemerintah. Sedangkan yang terakhir, untuk risiko kesinambungan fiskal, faktor yang mempengaruhi yaitu perubahan kebutuhan pembiayaan akibat perubahan perubahan asumsi makroekonomi dalam APBN.

Untuk mengantisipasi berbagai risiko tersebut, Pemerintah Indonesia telah menjalankan strategi pengelolaan utang secara aktif dengan memanfaatkan berbagai instrumen kebijakan untuk mengelola risiko utang seperti buyback, debt switch, debt swap, hedging, ALM, dan CMP/BSF. Namun khusus untuk hedging dan ALM pelaksanaannya masih terbatas.

Hedging menggunakan instrumen keuangan derivatif belum dapat dilaksanakan karena belum adanya pedoman teknis atau petunjuk pelaksanaan lebih jauh. Sedangkan pelaksanaan ALM masih terbatas pada isu likuiditas.

Telah dibentuk dan dilaksanakannya CMP dan BSF sebagai alat deteksi krisis pasar keuangan domestik sehingga dapat disusun langkah-langkah pencegahan untuk mencegah krisis yang berkelanjutan dan berdampak sistemik.

Secara umum hampir seluruh target indikator risiko utang pada Tahun 2014 berhasil tercapai.
Hanya beberapa indikator risiko kesinambungan fiskal seperti rasio utang terhadap PDB dibawah 24 persen gagal tercapai, karena realisasinya mencapai 24,7 persen. Kemudian rasio beban bunga utang terhadap penerimaan yang ditargetkan maksimal 8 persen, namun realisasinya mencapai 8,6 persen. Begitu pun dengan rasio beban bunga utang terhadap pendapatan yang mencapai 1,3 persen, melebihi yang ditargetkan maksimal 1,2 persen.

\subsection{Saran}

DJPPR agar melaksanakan lindung nilai dengan instrumen derivatif untuk optimalisasi pengelolaan risiko utang. Oleh karena itu, DJPPR diharapkan dapat meningkatkan koordinasi dengan Biro Hukum Setjen Kementerian Keuangan terkait tanggung jawab hukum, DJA terkait dengan penganggaran, DJPB terkait pencatatan akuntansi dan pelaporan dalam pelaksanaan transaksi lindung nilai menggunakan instrumen derivatif.

Kementerian Keuangan bersama-sama dengan BI dan Kementerian BUMN agar dapat melaksanakan ALM dalam skala nasional untuk transparansi dan akuntabilitas pengelolaan neraca gabungan antara Neraca Pemerintah, Neraca BI, dan Neraca BUMN. Selain itu dapat meningkatkan harmonisasi kebijakan antar lembaga dalam hal pengelolaan risiko keuangan negara dan risiko pasar, dan menghemat biaya untuk pelaksanaan kebijakan-kebijakan yang saling trade-off.

Mencermati hasil capaian beberapa indikator risiko kesinambungan fiskal yang tidak sesuai dengan target, DJPPR diharapkan dapat mengantisipasi perubahan kebutuhan pembiayaan dengan utang akibat realisasi defisit APBN melebihi yang direncanakan. Oleh karena itu DJPPR agar meningkatkan kehati-hatian dalam penentuan target indikator risiko dengan memperhatikan kondisi makroekonomi Indonesia dan faktor sentimen global lain yang mempengaruhi risiko pengelolaan utang. Lebih jauh lagi DJPPR agar dapat meningkatkan kualitas dan efisiensi dalam pengelolaan utang agar biaya/ beban bunga dapat dijaga pada level yang terkendali.

\section{IMPLIKASI DAN KETERBATASAN}

6.1. Utang Pemerintah terdiri atas dua komponen yaitu direct liabilities yaitu pinjaman dan SBN yang telah dibahas dalam penelitian ini, dan contingent liabilities yaitu kewajiban yang timbul atas kegiatan penjaminan pelaksanaan proyek/ kegiatan Pemerintah. Namun dalam penelitian ini utang yang disebabkan oleh kewajiban kontinjensi Pemerintah tidak dibahas lebih jauh karena unsur ketidakpastian risiko yang sulit diukur, 
keterbatasan data yang tersedia dan kemampuan penulis untuk mengolah data tersebut.

6.2. Terdapat risiko pengelolaan utang selain dari risiko nilai tukar, risiko tingkat bunga, risiko pembiayaan kembali dan risiko kesinambungan fiskal yang telah dibahas dalam penelitian ini, salah satunya adalah risiko operasional. Namun risiko operasional tidak dibahas lebih jauh karena ruang lingkupnya yang terlalu luas dan keterbatasan data yang tersedia.

\section{PENGHARGAAN (ACKNOWLEDGEMENT)}

Penulis mengucapkan terima kasih kepada semua pihak yang telah terlibat dalam penyusunan penelitian ini, khususnya kepada para narasumber di Direktorat Jenderal Pengelolaan Pembiayaan dan Risiko Kementerian Keuangan Republik Indonesia.

\section{DAFTAR PUSTAKA}

(2014). Strategi Pembiayaan Tahunan Melalui Utang Tahun 2015. Jakarta: DJPU Kementerian Keuangan RI

(2015). Profil Utang Pemerintah Pusat (Pinjaman dan Surat Berharga Negara) Edisi Desember 2015. Jakarta: DJPPR Kementerian Keuangan RI

(2014). Keputusan Menteri Keuangan Nomor 113/KMK.08/2014 tentang Strategi Pengelolaan Utang Negara Tahun 2014 s.d. 2017

. (2011). Keputusan Menteri Keuangan Nomor 175/KMK.08/2011 tentang Mekanisme Koordinasi Pembelian SBN Dalam Rangka Stabilisasi Pasar SBN di Lingkungan Kementerian Keuangan

(2013). Keputusan Menteri Keuangan Nomor 37/KMK.08/2013 tentang Strategi Pengelolaan Utang Negara Tahun 2013 s.d. 2016

(2010). Keputusan Menteri Keuangan Nomor 380/KMK.08/2010 jo. Keputusan Menteri Keuangan Nomor 514/KMK.08/2010 tentang Strategi Pengelolaan Utang Negara Tahun 2010 s.d. 2014

(2013). Keputusan Menteri Keuangan Nomor 455/KMK/08/2013 tentang Penetapan Level Kondisi Pasar SBN dalam Melaksanakan Protokol Manajemen Krisis Pasar SBN

(2013) Laporan Analisis Portofolio dan Risiko Utang Tahun 2010-2013. Jakarta: DJPU Kementerian Keuangan RI
(2014) Laporan Keuangan Pemerintah Pusat Audited Tahun 2005-2014

(2013). Peraturan Menteri Keuangan Nomor 12/PMK.08/2013 tentang Transaksi Lindung Nilai dalam Pengelolaan Utang Pemerintah

(2008). Peraturan Menteri Keuangan Nomor 191/PMK.09/2008 tentang Penerapan Manajemen Risiko di Kementerian Keuangan

(2014). Peraturan Menteri Keuangan Nomor 206/PMK.01/2014 tentang Organisasi dan Tata Kerja Kementerian Keuangan (2003). Undang-undang Nomor 17 Tahun 2003 tentang Keuangan Negara (2008). Undang-undang Nomor 19 Tahun 2008 tentang Surat Berharga Syariah Negara

Afrizal. (2014). Metode Penelitian Kualitatif, Sebuah Upaya Mendukung Penggunaan Penelitian Kualitatif dalam Berbagai Disiplin Ilmu. Jakarta: Rajagrafindo Persada.

Agenor, P.J. dan P.J Montiel. (1996). Development Macroeconomics. New Jersey: Princeton University Press.

Ahmad Nasikin, S.ST., Ak., M.M., Kepala Seksi Strategi Pembiayaan Tahunan, Subdirektorat Perencanaan dan Strategi Pembiayaan, Direktorat Strategi dan Portofolio Pembiayaan, Direktorat Jenderal Pengelolaan Pembiayaan dan Risiko, Kementerian Keuangan RI.

AM Best Company Inc. (2015, August 18). Indonesia Country Risk Report. Diakses dari http://www3.ambest.com/ratings/cr/repor ts/Indonesia.pdf

Arikunto, Suharsimi. (2004). Dasar-dasar Evaluasi Pendidikan. Jakarta: Bumi Aksara.

Bafadal, Azhar. (2005). Dampak Defisit dan Utang Pemerintah Terhadap Stabilitas Makro Ekonomi. Bogor: Institut Pertanian Bogor. Disertasi.

Bangura, S., D. Kitabire, dan R. Powell. (2000). External Debt Management in Low-Income Countries. Washington: IMF Working Paper, WP/00/196.

Bank Indonesia. (2016, February 1). Perkembangan Sovereign Rating Indonesia 2005 s.d. 2014. Diakses dari http://www.bi.go.id/en/iru/marketdata/indonesian-sovereignrating/Default.aspx

Bank Indonesia. (2016, January 21). Inflasi Indeks Harga Konsumen Indonesia Year on Year pada 2005 s.d. 2015. Diakses dari http://www.bi.go.id/en/moneter/inflasi/da ta/Default.aspx 
Bank Indonesia. (2016, January 5). BI Rate Periode 2005 s.d. 2015. Diakses dari http://www.bi.go.id/id/moneter/birate/data/Default.aspx

Bank Indonesia. Laporan Perekonomian Indonesia Tahun 2005-2014

Bluedorn, John dan Daniel Leigh. (2011). Revisiting the Twin Deficits Hypothesis: The Effect of Fiscal Consolidation on the Current Account. Washington: IMF Economic Review.

Cassard, Marcell dan David Folkerts Landau. (1997). Risk Management of Sovereign Assets and Liabilities. Washington: IMF Working Paper.

Cassard, Marcell dan David Folkerts Landau. (1997, December). Sovereign Debt: Managing the Risks. IMF Finance and Development Magazine, 12-15.

Cavallo, Michele. (2005). Understanding the Twin Deficits: New Approaches, New Result. San Fransisco: Federal Reserve Bank of San Fransisco.

Corbin, Juliet dan Anselm Strauss. (1998). Basic of Qualitative Research: Techniques and Procedures for Developing Grounded Theory. California: Sage Publications.

Deutsche Bank. (2016, February 1). Pergerakan CDS 5 Years Indonesia, Brazil, Thailand, dan Turki. Diakses dari https://www.dbresearch.com/servlet/rewe b2.ReWEB?rwnode=DBR_INTERNET_ENPROD\$NAVIGATION\&rwobj=CDS.calias\&rws ite=DBR_INTERNET_EN-PROD

Direktorat Jenderal Pengelolaan Pembiayaan dan Risiko. (2015). Revisi Strategi Pembiayaan Tahunan Melalui Utang Tahun 2015. Jakarta: DJPPR Kementerian Keuangan RI

Direktorat Jenderal Pengelolaan Pembiayaan dan Risiko. (2016, January 31). Porsi Kepemilikan Asing SBN Rupiah Tradable Per 31 Desember 2015. Diakses dari http://www.djppr.kemenkeu.go.id/page/loa $\mathrm{d} / 29$

Direktorat Jenderal Pengelolaan Utang. (2013). Strategi Pembiayaan Tahunan Melalui Utang Tahun 2014. Jakarta: DJPU Kementerian Keuangan RI

Direktur Jenderal Pengelolaan Utang. Keputusan Direktur Jenderal Pengelolaan Utang Nomor 4/PU/2014 tentang Indeks Protokol Manajemen Krisis Pasar SBN dan Indikator Pencabutan Level Kondisi Pasar SBN

Djojosoedarso, Soeisno. (2003). Prinsip-prinsip Manajemen Risiko dan Asuransi. Edisi Revisi. Jakarta: Salemba Empat.

Farid Arif Wibowo, S.E., Ak., MID.Ec., Kepala Seksi Analisis Risiko Aset dan Kewajiban Lintas Generasi, Subdirektorat Pengelolaan Risiko Aset dan Kewajiban Negara, Direktorat
Pengelolaan Risiko Keuangan Negara, Direktorat Jenderal Pengelolaan Pembiayaan dan Risiko, Kementerian Keuangan RI.

Hanafi, Mamduh M. (2006). Manajemen Risiko. Yogyakarta: Unit Penerbit dan Percetakan Sekolah Tinggi Manajemen YPKN.

Harvey, Campbell R. (2011, May 17). Yield Curve Inversions and Future Economic Growth. Diakses dari https://faculty.fuqua.duke.edu/ charvey/R esearch/Professional_Materials/Term_Struct ure_May_17_2011.pdf

Haryati, E. (2001). Dampak Defisit APBN Terhadap Pertumbuhan Ekonomi. Jakarta: Institute for Development of Economics and Finance.

Horcher, Karen A. (2005). Essentials of Financial Risk Management. New Jersey: John Wiley \& Sons Inc.

Hossain, A. dan A. Chowdury. (1998). Open Economy Macroeconomics for Developing Countries. Cheltenham: Edward Elgar Publishing Ltd.

Ikatan Bankir Indonesia. (2015). Manajemen Risiko. Jakarta: Gramedia Pustaka Utama.

Indonesia Bond Price Agency. (2016, February 1). Posisi Yield Curve Indonesia Per 29 Januari 2016. Diakses dari http://www.ibpa.co.id/DataPasarSuratUtan g/HargadanYieldHarian/tabid/84/Default.as $\mathrm{px}$

International Monetary Fund. (2014). Revised Guidelines for Public Debt Management. Washington: IMF Policy Paper.

International Monetary Fund. (2014). Sovereign Asset-Liability Management-Guidance for Resource-Rich Economies. Washington: IMF Working Paper.

K.M. Nuruddin, S.H., M.M., Kepala Seksi Analisis Pasar Surat Utang Negara, Subdirektorat Analisis Keuangan dan Pasar Surat Utang Negara, Direktorat Surat Utang Negara, Direktorat Jenderal Pengelolaan Pembiayaan dan Risiko, Kementerian Keuangan RI.

Keown J. Arthur dan Scott David F. (2000). DasarDasar Manajemen Keuangan. Jakarta: Salemba Empat.

Keynes, John Maynard. 1936. The General Theory of Employment, Interest and Money. London: Macmillan.

Macrotrends. (2016, February 1). TED Spread 2005 s.d. 2015. Diakses dari http://www.macrotrends.net/1447/tedspread-historical-chart

Macrotrends. (2016, March 3). Harga Minyak Dunia Periode 2005 s.d. 2015. Diakses dari http://www.macrotrends.net/1369/crudeoil-price-history-chart

Macrotrends. (2016. January 5). Tren Pergerakan LIBOR Periode 2005 s.d. 2014. Diakses dari 
http://www.macrotrends.net/1433/historic al-libor-rates-chart

Mankiw, N. Gregory. (2006). Makroekonomi Edisi Keenam. Jakarta: Penerbit Erlangga.

Menteri Keuangan Republik Indonesia. Keputusan Menteri Keuangan Nomor 447/KMK.06/2005 tentang Strategi Pengelolaan Utang Negara Tahun 2005 s.d. 2009

Peltier, Thomas R. (2001). Information Security Risk Analysis. New York: Aurbach.

Pemerintah Republik Indonesia. Undang-undang Nomor 24 Tahun 2002 tentang Surat Utang Negara.

Pougue, T. F. dan L.G. Sgontz. (1978). Government and Economic Choice: an Introduction to Public Finance. Boston: Houghton Mifflin Company.

Ricardo, David. (1820). Essay on Funding System.

Sigma. (2013). Government Debt Management and Operational Risk: A Risk Management Framework and Its Application in Turkey. Paris: OECD.

Storkey, Ian. (2001, May). Sovereign Debt Management: A Risk Management Focus. Finance and Treasury Professional, 7-10.

Sujarweni, V. Wiratna. (2014). Metodologi Penelitian: Lengkap, Praktis dan Mudah Dipahami. Yogyakarta: Pustaka Baru Press.

Suminto. (2006). Rescheduling Utang Pemerintah Melalui Paris Club. Majalah Treasury Indonesia No.1/2006 dan No. 2/2006.

Suriadi, La Ode. (2013). Pembiayaan Defisit dengan Utang dan Ketahanan Fiskal Indonesia. Kendari: Journal the Winners Vol. 14 No. 2/2013.

The Institute of Risk Management. (2015, November 11). Risk Management Framework, diakses dari https://www.theirm.org/media/886059/AR MS_2002_IRM.pdf

Trading Economics. (2016, January 21). PDB Indonesia pada 2005 s.d. 2014. Diakses dari http://www.tradingeconomics.com/indones ia/gdp

Vaughan, Emmet J. dan Curtis M. Elliot. (2008). Fundamentals of Risk and Insurance. Edisi ke-10. New York: John Wiley and Sons Inc.

Widodo, Boediarso Teguh. (2005). Implikasi Pembiayaan Defisit APBN Terhadap Kesinambungan Fiskal (Fiscal Sustainability): Studi Kasus APBN Indonesia. Depok: Universitas Indonesia. Tesis.

XE. (2016, January 4). Kurs Rupiah terhadap USD pada Periode 2005 s.d. 2104. Diakses dari http://www.xe.com/currencycharts/?from= USD\&to=IDR\&view $=10 \mathrm{Y}$ 